\title{
Iminosugars Spiro-Linked with Morpholine-Fused 1,2,3-Triazole: Synthesis, Conformational Analysis, Glycosidase Inhibitory Activity, Antifungal Assay, and Docking Studies
}

\author{
Shrawan R. Chavan, ${ }^{\dagger}$ Kishor S. Gavale, ${ }^{\dagger}$ Ayesha Khan, ${ }^{\dagger}$ Rakesh Joshi, ${ }^{\S}$ Navanath Kumbhar, ${ }^{\dagger}$ \\ Debamitra Chakravarty," and Dilip D. Dhavale*, ${ }^{\dagger}, \|_{\odot}$
}

${ }^{\dagger}$ Garware Research Centre, Department of Chemistry, ${ }^{\ddagger}$ Department of Chemistry, ${ }^{\S}$ Institute of Bio-informatics and Biotechnology, and ${ }^{\|}$Central Instrumentation Facility, Savitribai Phule Pune University (Formerly University of Pune), Ganeshkhind Road, Pune 411007, India

\section{Supporting Information}

ABSTRACT: Synthesis of iminosugars 1, 2, 3a, and $\mathbf{4 a}$ and $\mathrm{N}$-alkyl (ethyl, butyl, hexyl, octyl, decyl, and dodecyl) derivatives $\mathbf{3 b}-\mathbf{g}$ and $\mathbf{4 b}-\mathbf{g}$ spiro-linked with morpholinefused 1,2,3-triazole is described. Conformation of the piperidine ring in each spiro-iminosugar was evaluated by ${ }^{1} \mathrm{H}$ NMR spectroscopy, and conformational change in N-alkylated compounds $\mathbf{4 b}-\mathbf{g}$ with respect to parent spiro-iminosugar $\mathbf{4 a}$
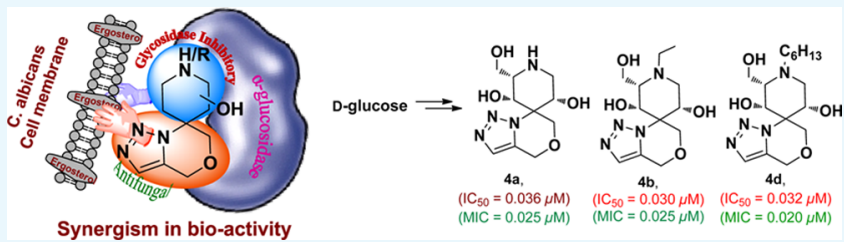
is supported by density functional theory calculations. Out of 16 new spiro-iminosugars, the spiro-iminosugars $3 a\left(\mathrm{IC}_{50}=0.075\right.$ $\mu \mathrm{M})$ and $4 \mathrm{a}\left(\mathrm{IC}_{50}=0.036 \mu \mathrm{M}\right)$ were found to be more potent inhibitors of $\alpha$-glucosidase than the marketed drug miglitol ( $\mathrm{IC}_{50}$ $=0.100 \mu \mathrm{M})$. In addition, 3a (minimum inhibition concentration $(\mathrm{MIC})=0.85 \mu \mathrm{M})$ and $4 \mathrm{a}(\mathrm{MIC}=0.025 \mu \mathrm{M})$ showed more potent antifungal activity against Candida albicans than antifungal drug amphotericin $\mathrm{b}(\mathrm{MIC}=1.25 \mu \mathrm{M})$. In few cases, the Nalkyl derivatives showed increase of $\alpha$-glucosidase inhibition and enhancement of antifungal activity compare to the respective parent iminosugar. The biological activities were further substantiated by molecular docking studies.

\section{INTRODUCTION}

Glycosidases play a key role in intestinal digestion, posttranslational processing of glycoproteins, endoplasmic reticulum-associated degradation mechanisms, and the lysosomal catabolism of glycoconjugates. ${ }^{1}$ Any malfunction in this process leads to discomforts in the body, and in case of long-run processes, one suffers from disease. ${ }^{2}$ For example, disorders in functioning of amylase and/or $\alpha$-glucosidase enzymes results in alteration in the blood glucose level, a condition noted as diabetes mellitus type-II (DM-II). ${ }^{3}$ Patients suffering from longterm DM-II develop low immunity ${ }^{4}$ and fall as a prey to a variety of comorbidities, such as retinopathy, ${ }^{5}$ nephropathy, ${ }^{6}$ neuropathy, ${ }^{7}$ infections, ${ }^{8}$ and many more. ${ }^{9}$ In particular, sugar damp in diabetes nurtures the infections of Candida albicans yeast in mouth, skin, nails, and surroundings of urethral openings. ${ }^{10}$ In such cases of comorbidity discomforts, an effective treatment is a challenge and prescription of two separate drugs is a common medicinal practice. Among a variety of antidiabetic drugs, an iminosugar (cyclic sugars with the nitrogen atom in place of the ring oxygen atom) class of compound, namely, glycet/miglitol I (Figure 1) is consumed for the treatment of DM-II, ${ }^{11}$ whereas, for the treatment of fungal infection, 1,2,4-triazole-containing drug fluconazole ${ }^{12}$ is practiced. Alternatively, hybrid/chimeric drugs, in which two pharmacophores are present in one molecule and thus showing dual therapeutic mechanism, would have been the most appropriate choice. ${ }^{13,14}$ In this direction, a number of hybrid drugs were synthesized and evaluated for biological activities. ${ }^{14}$ Among these, iminosugars attached with other pharmacophores have attracted a great deal of interest. ${ }^{1,15}$ For example, iminosugar fused with tetrazole II (Figure 1) showed antitubercular as well as $\alpha$-rhamnosidase inhibitory activity. ${ }^{16}$ Iminosugar fused with imidazole ring, namely, nagstatin (III) is an $N$-acetyl- $\beta$-glucosaminidase inhibitor and acts as an anticancer agent, ${ }^{1,17}$ whereas iminosugar fused with 1,2,4triazole IV shows inhibition toward $\alpha$-mannosidase along with anticancer activity. ${ }^{1}$ A few examples of the iminosugars spirolinked with other pharmacophores are also known. ${ }^{a, 18}$ Laroche et al. reported a titanium-mediated aminocyclopropanation of nitriles to give pyrrolidine iminosugar spiro-linked with cyclopropane $\mathbf{V} .{ }^{19}$ Vankar and co-workers utilized the RCM strategy in the synthesis of iminosugar spiro-linked with the sugar pyranose VI. ${ }^{20}$ Compain and co-workers used $\mathrm{C}-\mathrm{H}$ amination and RCM methodology to build 5-azaspiro[3,4]octane VII skeleton. $^{21}$

Our group has exploited Corey-link approach with 3-oxo1,2;5,6-diisopropylidene-D-gluco-furanose to give $\mathrm{C}_{3}$-azido-3formyl-substituted D-gluco-furanose that was elaborated toward the synthesis of spiro-iminosugars VIIIa/VIIIb, which showed a promising $\alpha$-glucosidase inhibitory activity. ${ }^{22}$ In the

Received: September 4, 2017

Accepted: October 13, 2017

Published: October 26, 2017 
<smiles>OCCN1C[C@H](O)[C@@H](O)[C@H](O)[C@H]1CO</smiles>

I, Miglitol<smiles>OC[C@H]1[C@@H](O)[C@H](O)[C@@H](O)c2nncn21</smiles><smiles>O[C@@H]1[C@H](O)CN[C@]12[C@@H](O)[C@@H](O)[C@@H]2O</smiles>

VII<smiles>C[C@H]1[C@@H](O)[C@H](O)[C@H](O)c2nnnn21</smiles>

II<smiles>OC[C@H]1NC2(CC2)[C@H](O)[C@@H]1O</smiles><smiles>O=C1CC[C@]2(N1)[C@H](O)[C@H](O)CNC[C@H]2O</smiles>

VIIIb $n=0$<smiles>CC(=O)N[C@H]1c2nc(CC(=O)O)cn2[C@@H](CO)[C@H](O)[C@@H]1O</smiles><smiles></smiles>

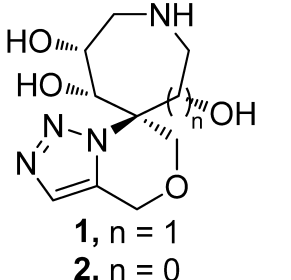<smiles>[R]C1NC[C@@H](O)[C@@]2(COCc3cnnn32)[C@H]1O</smiles>

3a, $\mathrm{R}=\mathrm{R}^{\prime}=\mathrm{H}$,

4a, $\mathrm{R}=\mathrm{CH}_{2} \mathrm{OH}, \mathrm{R}^{\prime}=\mathrm{H}$,

3b, $R=H, R^{\prime}=$ ethyl

3c, $R=H, R^{\prime}=$ butyl

4b, $\mathrm{R}=\mathrm{CH}_{2} \mathrm{OH}, \mathrm{R}^{\prime}=$ ethyl

3d, R = H, R' = hexyl

4c, $\mathrm{R}=\mathrm{CH}_{2} \mathrm{OH}, \mathrm{R}^{\prime}=$ butyl

3e, $R=H, R^{\prime}=$ octyl

4d, $\mathrm{R}=\mathrm{CH}_{2} \mathrm{OH}, \mathrm{R}^{\prime}=$ hexyl

3f, $\mathrm{R}=\mathrm{H}, \mathrm{R}^{\prime}=$ decyl

$4 \mathrm{e}, \mathrm{R}=\mathrm{CH}_{2} \mathrm{OH}, \mathrm{R}^{\prime}=$ octyl

$3 g, R=H, R^{\prime}=$ dodecyl

4f, $\mathrm{R}=\mathrm{CH}_{2} \mathrm{OH}, \mathrm{R}^{\prime}=$ decyl

4g, $\mathrm{R}=\mathrm{CH}_{2} \mathrm{OH}, \mathrm{R}^{\prime}=$ dodecyl

Figure 1. Known iminosugars and target molecules.<smiles>[R]C([R])(N)COCC#CC</smiles>

IXa-c<smiles>[R4][C@@H]1COCC([R])([R])n2nncc21</smiles>

a, $\mathrm{R}_{1}=\mathrm{R}_{2}=\mathrm{H} ; \mathrm{k}_{\mathrm{rel}}=1$

$\mathrm{IX} / \mathrm{Xb}, \mathrm{R}_{1}=\mathrm{R}_{2}=\mathrm{CH}_{3} ; \mathrm{k}_{\text {rel }}=8$

$\mathbf{I X} / \mathbf{X b}, \mathrm{R}_{1}=\mathrm{R}_{2}=-\left(\mathrm{CH}_{2}\right)_{4}-\mathrm{k}_{\mathrm{rel}}=7$

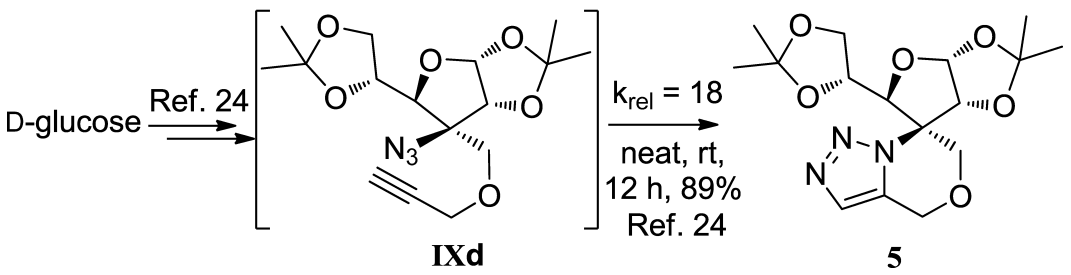

Figure 2. Catalyst-free AAC reaction in IXa-d.

continuation of our work, we now report the synthesis of tricyclic azepine 1, piperidine iminosugars $2,3 \mathbf{a}-\mathbf{g}$, and iminosugars $4 \mathbf{a}-\mathbf{g}$ spiro-linked with the morpholine-fused 1,2,3-triazol. The conformations ${ }^{1} C_{4} /{ }^{4} C_{1}$ were obtained on the basis of the ${ }^{1} \mathrm{H}$ NMR study and substantiated by density functional theory (DFT) studies. The glycosidase inhibitory and antifungal (on Candida albicans yeast cells) activities were evaluated. Among the 16 targeted molecules, iminosugar 3a $\left(\mathrm{IC}_{50}=0.075 \mu \mathrm{M}\right)$ and iminosugar $4 \mathrm{a}\left(\mathrm{IC}_{50}=0.036 \mu \mathrm{M}\right)$ were found to be highly potent $\alpha$-glucosidase inhibitors compared to miglitol I $\left(\mathrm{IC}_{50}=0.100 \mu \mathrm{M}\right)$. In addition, 3a (minimum inhibition concentration $(\mathrm{MIC})=0.85 \mu \mathrm{M})$ and $4 \mathrm{a}(\mathrm{MIC}=$ $0.025 \mu \mathrm{M})$ were noticed to be highly potent antifungal agents compared to marketed drug amphotericin $\mathrm{b}(\mathrm{MIC}=1.25 \mu \mathrm{M})$. As the hybrid drugs are known to increase cellular uptake that augment the specific pharmacological activity, ${ }^{b, 23}$ an analogous trend was noticed with the spiro-iminosugars $\mathbf{1}, \mathbf{2}, \mathbf{3 a}-\mathbf{g}$, and
$4 a-g$ in the augmentation of the glycosidase inhibitory as well as antifungal activity due to the presence of iminosugar and triazole pharmacophores in the same molecule. Our results toward the synthesis, conformations, glycosidase, and antifungal activity as well as molecular docking studies of spiroiminosugars are described herein.

\section{RESULTS AND DISCUSSION}

Synthesis of Spiro-Iminosugars (1, 2, 3a-g, and 4ag). Recently, we have studied the role of gem-disubstituent effect in intramolecular alkyne-azide 1,3-dipolar cycloaddition (AAC) reaction with O-propargylated azido compounds IXa-d by experimental kinetic data and thermodynamic parameters obtained from computational studies (Figure 2). ${ }^{24}$ During this study, we noticed that the AAC reaction of 1,2;5,6-di-Oisopropylidene-3-O-propargyl-3-azido-D-glucofuranose IXd in the presence or absence of solvent occurred spontaneously at 
Scheme 1. Synthesis of Spiro-Iminosugars 1 and $2^{a}$

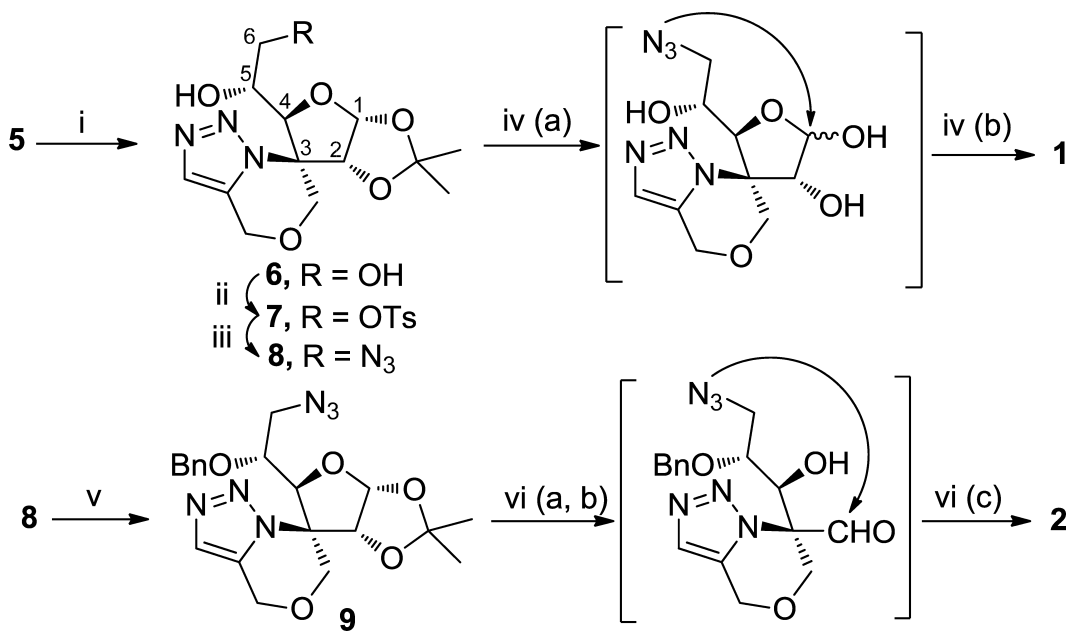

${ }^{a}$ Reagents and conditions: (i) $60 \%$ aq AcOH, $60{ }^{\circ} \mathrm{C}, 3 \mathrm{~h}, 92 \%$; (ii) $\mathrm{Bu}_{2} \mathrm{SnO}, \mathrm{TsCI}$, tetraethylammonium (TEA), room temperature (RT), $1 \mathrm{~h}, 97 \%$; (iii) $\mathrm{NaN}_{3}$, tetrabutylammonium iodide (TBAI), DMF, $95{ }^{\circ} \mathrm{C}, 3 \mathrm{~h}, 89 \%$; (iv) (a) TFA $/ \mathrm{H}_{2} \mathrm{O}(3: 1), 0{ }^{\circ} \mathrm{C}, 3 \mathrm{~h},(\mathrm{~b}) 10 \% \mathrm{Pd} / \mathrm{C}, \mathrm{H}_{2}, 80 \mathrm{psi}, 24 \mathrm{~h}, \mathrm{RT}$, 71\%; (v) BnBr, NaH, THF, $0{ }^{\circ} \mathrm{C}$ to RT, 3 h, 75\%; (vi) (a) TFA/ $\mathrm{H}_{2} \mathrm{O}$ (3:1), RT, 3 h, (b) $\mathrm{NalO}_{4}$, acetone/water (8:2), 3 h, (c) $10 \% \mathrm{Pd} / \mathrm{C}, \mathrm{H}_{2}, 120$ psi, $30 \mathrm{~h}, 68 \%$.

Scheme 2. Synthesis of Spiro-Iminosugars $3 a-g$ and $4 a-g^{a}$

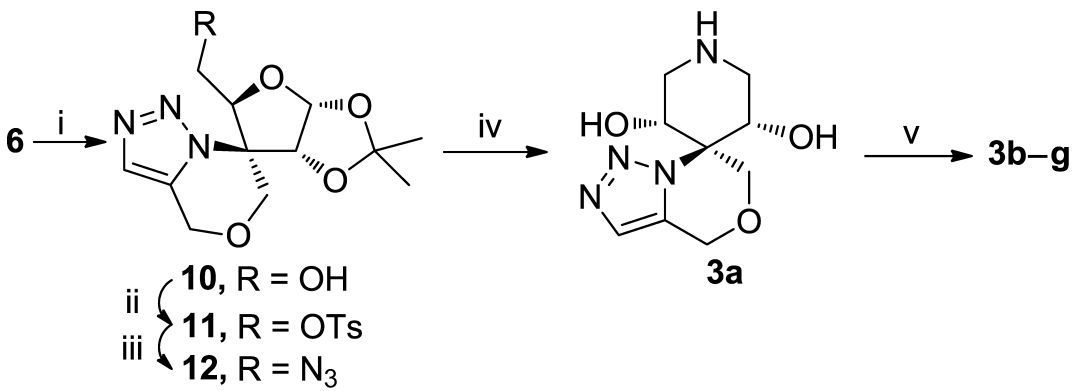

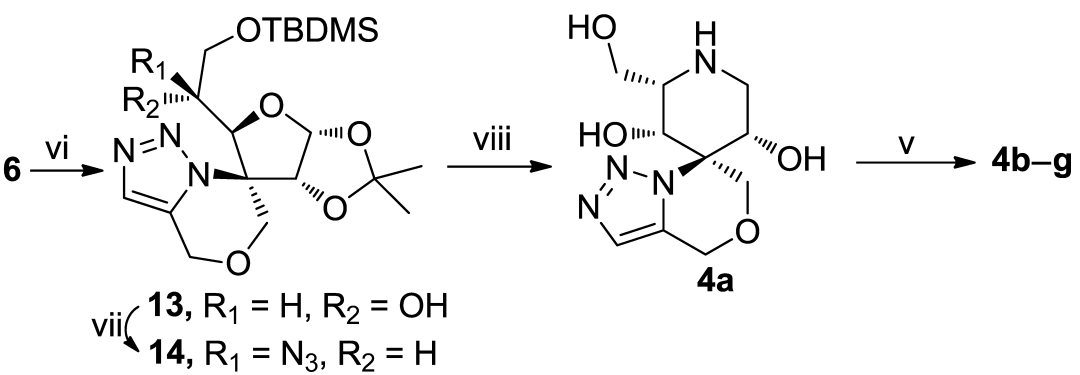

${ }^{a}$ Reagents and conditions: (i) (a) $\mathrm{NalO}_{4}$, acetone/water (4:1), $0{ }^{\circ} \mathrm{C}$ to $\mathrm{RT} 2 \mathrm{~h},(\mathrm{~b}) \mathrm{NaBH}_{4}, \mathrm{MeOH}, 0{ }^{\circ} \mathrm{C}, 1 \mathrm{~h}, 88 \%$ two steps; (ii) TsCI, pyridine,

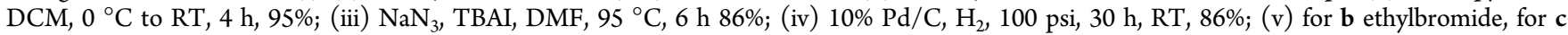
butylbromide, for $\mathbf{d}$ hexylbromide, for e octylbromide, for $\mathrm{f}$ decylbromide, for $\mathrm{g}$ dodecylbromide, $\mathrm{K}_{2} \mathrm{CO}_{3}, \mathrm{DMF}, 80^{\circ} \mathrm{C}, 1 \mathrm{~h}$, and for $3 \mathrm{~b}-\mathrm{g}, 60{ }^{\circ} \mathrm{C}, 2 \mathrm{~h}$ for $4 \mathbf{b}-\mathrm{g}$; (vi) TBDMSCI, imidazole, DCM, $2 \mathrm{~h}$, RT, 95\%; (vii) (a) OTf 2 , pyridine, DMAP, DCM, $0{ }^{\circ} \mathrm{C}, 30 \mathrm{~min},(\mathrm{~b}) \mathrm{NaN}, \mathrm{DMF}, 65^{\circ} \mathrm{C}, 1 \mathrm{~h}, 92 \%$ two steps; (viii) (a) TFA $/ \mathrm{H}_{2} \mathrm{O}(3: 1), 3 \mathrm{~h}, 0{ }^{\circ} \mathrm{C}$, (b) $10 \% \mathrm{Pd} / \mathrm{C}, \mathrm{H}_{2}, 120 \mathrm{psi}, 24 \mathrm{~h}, \mathrm{RT}, 78 \%$.

ambient temperature to afford morpholine-fused 1,2,3,-triazole moiety spirocyclic with D-gluco-furanose 5 in $89 \%$ yield. We thought of exploiting the same intermediate 5 , by suitable manipulation of 5,6- and 1,2-O-isopropylidene groups of Dgluco-furanose, for the synthesis of targeted spiro-iminosugars.

As shown in Scheme 1, selective deprotection of 5,6-Oisopropylidene group in 5 with $\mathrm{AcOH} / \mathrm{H}_{2} \mathrm{O}(3: 2)$ at $60{ }^{\circ} \mathrm{C}$ afforded diol 6 . The primary hydroxyl group in 6 was protected as -OTs group using $\mathrm{Bu}_{2} \mathrm{SnO}$ and $\mathrm{TsCl}$ in triethylamine to get 7, which on nucleophilic displacement of $\mathrm{C} 6-\mathrm{OT}$ sroup with $\mathrm{NaN}_{3}$ in dimethylformamide (DMF) afforded C6- azido compound 8 in $89 \%$ yield. In the next step, hydrolysis of 1,2-O- isopropylidene group in 8 with TFA $/ \mathrm{H}_{2} \mathrm{O}(3: 1)$ at $0{ }^{\circ} \mathrm{C}$ gave an anomeric mixture of hemiacetal (as evident from the ${ }^{1} \mathrm{H}$ NMR of crude product), which on intramolecular reductive aminocyclization under hydrogenation condition, using $10 \% \mathrm{Pd} / \mathrm{C}$ in methanol at 80 psi pressure, gave azepine iminosugar spirolinked with the morpholine-fused 1,2,3-triazole 1 in $71 \%$ yield.

For the synthesis of spiro-iminosugar 2, it is necessary to remove anomeric $\mathrm{C} 1$ carbon atom in compound 8 , for which it is necessary to protect $\mathrm{C} 5-\mathrm{OH}$ group with benzyl derivative. Thus, 8 was reacted with $\mathrm{NaH}$ and benzyl bromide in THF to get 6-azido 5-benzyloxy derivative 9 (Scheme 1). Hydrolysis of 1,2-acetonide in 9 with TFA/ $\mathrm{H}_{2} \mathrm{O}(3: 1)$ followed by treatment 

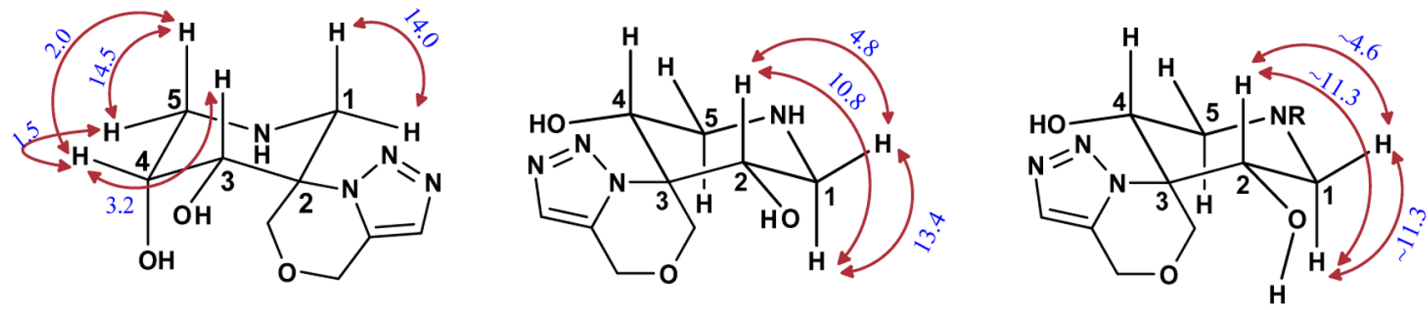

$2,{ }^{1} C_{4}$

3a, ${ }^{4} C_{1}$

$\mathbf{3 b}-\mathbf{g},{ }^{4} C_{1}$

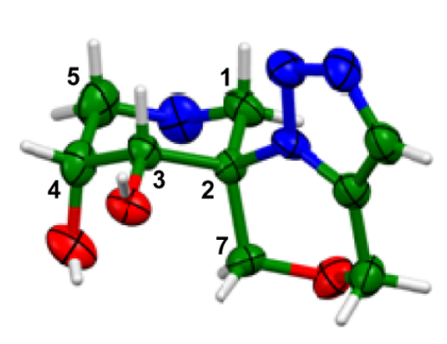

2

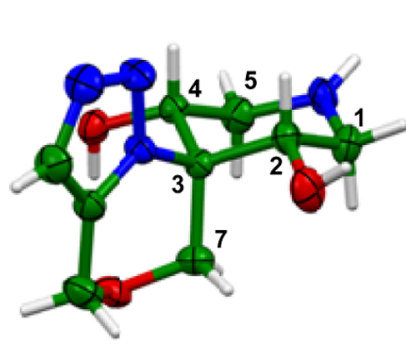

3a

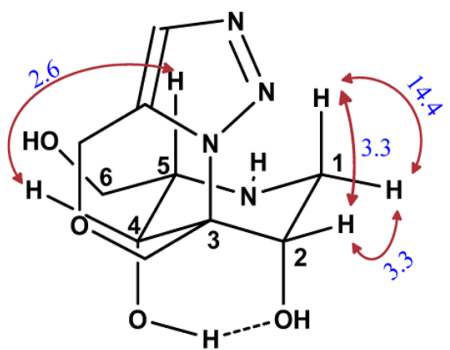

4a, ${ }^{1} C_{4}$

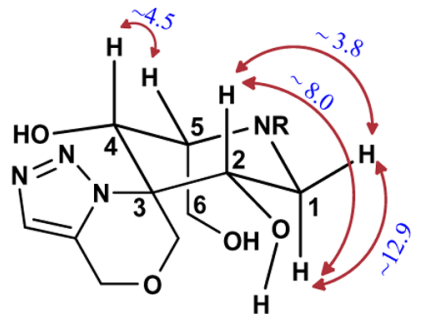

$\mathbf{4 b}-\mathbf{g},{ }^{4} C_{1}$

Figure 3. Conformations of spiro-iminosugars $2,3 a-g$, and $4 a-g$ and ORTEP diagram of 2 and $3 \mathbf{a}$.

with $\mathrm{NaIO}_{4}$ in acetone $/ \mathrm{H}_{2} \mathrm{O}(8: 2)$ and intramolecular reductive aminocyclization of $\mathrm{C} 6-$ azido group with $\mathrm{C} 2-$ formyl group using $\mathrm{H}_{2}$ in $10 \% \mathrm{Pd} / \mathrm{C}$ at 120 psi afforded piperidine iminosugar spiro-linked with morpholine-fused 1,2,3-triazole 2 in $68 \%$ yield.

The synthesis of iminosugar 3a started from the diol 6. Thus, reaction of 6 with $\mathrm{NaIO}_{4}$ in acetone $/ \mathrm{H}_{2} \mathrm{O}(8: 2)$ at $0{ }^{\circ} \mathrm{C}$ to $\mathrm{RT}$ followed by treatment with $\mathrm{NaBH}_{4}$ in $\mathrm{MeOH}$ at $0{ }^{\circ} \mathrm{C}$ afforded $\mathrm{D}$-xylofuranose derivative 10 (Scheme 2). Compound $\mathbf{1 0}$ was treated with $\mathrm{TsCl}$ in pyridine to give -OTs derivative 11, which on nucleophilic displacement using $\mathrm{NaN}_{3}$ in DMF afforded C5- azido compound 12. Finally, hydrolysis of 1,2-acetonide group in 12 with TFA $/ \mathrm{H}_{2} \mathrm{O}$ (3:1) followed by intramolecular aminocyclization using $\mathrm{H}_{2}$ in $10 \% \mathrm{Pd} / \mathrm{C}$ at 100 psi afforded 3a in $86 \%$ yield. In general, the $\mathrm{N}$-alkylated derivatives of iminosugars showed enhanced glycosidase inhibitory activity compared to their parent iminosugars. ${ }^{25}$ Thus, reaction of $3 \mathbf{a}$ with different alkyl bromides (alkyl = ethyl, butyl, hexyl, octyl, decyl, and dodecyl) in the presence of $\mathrm{K}_{2} \mathrm{CO}_{3}$ in $\mathrm{DMF}$ at $80^{\circ} \mathrm{C}$ afforded corresponding $\mathrm{N}$-alkyl derivatives $\mathbf{3 b}-\mathbf{g}$ in good yield (Scheme 2).

Iminosugar 4a was prepared from compound 6 (Scheme 2). Thus, selective protection of C6- primary hydroxy functionality in 6 with TBDMSCl in the presence of imidazole in dry dichloromethane afforded C6-OTBDMS compound 13. Reaction of 13 with triflic anhydride in $\mathrm{Et}_{3} \mathrm{~N}$ in dry dichloromethane afforded C5-OTf derivative, which was directly treated with $\mathrm{NaN}_{3}$ in DMF to get $\mathrm{C5}-$ azido derivative 14 with inversion of configuration at $\mathrm{C} 5$, as evident from the ${ }^{1} \mathrm{H}$ NMR spectrum $\left(J_{4,5}=1.5 \mathrm{~Hz}\right.$ in L-ido derivative against $J_{4,5}$ $=6.0 \mathrm{~Hz}$ in $\mathrm{D}$-gluco derivative in 13). Finally, cleavage of 1,2acetonide group in $\mathbf{1 4}$ with TFA/ $\mathrm{H}_{2} \mathrm{O}(3: 1)$ and intramolecular reductive aminocyclization with $\mathrm{H}_{2}$ in $10 \% \mathrm{Pd} / \mathrm{C}$ in $\mathrm{MeOH}$ at 120 psi and room temperature afforded $4 \mathrm{a}$ in $78 \%$ yield. $\mathrm{N}$ Alkylations of $\mathbf{4 a}$ with alkyl bromides (alkyl = ethyl, butyl, hexyl, octyl, decyl, and dodecyl) using $\mathrm{K}_{2} \mathrm{CO}_{3}$ in DMF at $60{ }^{\circ} \mathrm{C}$ afforded $\mathrm{N}$-alkyl iminosugars $\mathbf{4 b}-\mathbf{g}$, respectively (Scheme 2 ).

Conformational Analysis for $\mathbf{2}, \mathbf{3 a}-\mathbf{g}$, and $\mathbf{4 a - g}$. It is known that six-membered piperidine iminosugars exist in ${ }^{4} C_{1}$ or ${ }^{1} C_{4}$ conformations, depending on the substituents present on the ring. ${ }^{26}$ These conformations play a key role in deciding the binding property of iminosugars with enzymes rendering the glycosidase inhibition activity. ${ }^{27}$ In view of this fact, conformational aspects of newly synthesized spiro-linked iminosugars $2,3 \mathrm{a}-\mathrm{g}$, and $\mathbf{4 a}-\mathrm{g}$ were studied using ${ }^{1} \mathrm{H}$ NMR spectroscopy at neutral $\mathrm{pH}$. In case of iminosugar 2 , the assignment of $\mathrm{H} 3$ and $\mathrm{H} 4$ proton signals was difficult as these protons were obscured in the deuterated water (HOD). To resolve the spectra, we studied the temperature-dependent ${ }^{1} \mathrm{H}$ NMR spectrum of 2 in $\mathrm{D}_{2} \mathrm{O}$ as the HOD signal at $\delta 4.85$ and 22 ${ }^{\circ} \mathrm{C}$ is known to shift upfield with increasing the temperature, and at $72{ }^{\circ} \mathrm{C}$, it appears at $\delta 4.30 .{ }^{28}$ Therefore, the ${ }^{1} \mathrm{H}$ NMR spectrum of 2 in $\mathrm{D}_{2} \mathrm{O}$ was recorded at different temperatures of 22, 32, 52, and $72{ }^{\circ} \mathrm{C}$ (Figure S13). At $72{ }^{\circ} \mathrm{C}$, the doublet at $\delta$ 4.72 with $J=3.2 \mathrm{~Hz}$ was assigned to $\mathrm{H} 3$ and a narrow multiplate at $\delta 4.20$ was assigned to $\mathrm{H} 4$ on the basis of the DEPT-135, ${ }^{1} \mathrm{H}-{ }^{1} \mathrm{H}$ COSY, and ${ }^{1} \mathrm{H}-{ }^{13} \mathrm{C}$ HSQC NMR techniques (Figures S14-S16). The protons appearing at $\delta$ $3.10(\mathrm{dd}, J=14.4,1.5 \mathrm{~Hz}, 1 \mathrm{H})$ and $\delta 2.97(\mathrm{dd}, J=14.4,2.0 \mathrm{~Hz}$, $1 \mathrm{H})$ were assigned to $\mathrm{H} 5 \mathrm{e}$ and $\mathrm{H} 5 \mathrm{a}$, respectively. Other signals were unchanged, indicating no change in the conformation of 2 even at high temperature. With these ${ }^{1} \mathrm{H}$ NMR data, two conformations ${ }^{4} C_{1}$ and ${ }^{1} C_{4}$ were considered for compound 2 . The coupling constants between H5a (axial) and $\mathrm{H} 4$ and between $\mathrm{H} 4$ and $\mathrm{H} 3$ are decisive in determining the conformation.

In the ${ }^{1} \mathrm{H}$ NMR spectrum of 2 , a small coupling constant value between $\mathrm{H} 5 \mathrm{a} / \mathrm{H} 5 \mathrm{e}$ and $\mathrm{H} 4(\mathrm{~J} \approx 1.7 \mathrm{~Hz})$ indicated the cisrelative stereochemistry with the equatorial orientation of $\mathrm{H} 4$ (Figure 3). In accordance with this, H3 (axial) appeared as a doublet with a small coupling constant value $\left(J_{4,5}=3.2 \mathrm{~Hz}\right)$, showing cis-relative stereochemistry between $\mathrm{H} 3$ and $\mathrm{H} 4$. On the basis of these data, the ${ }^{1} C_{4}$ conformation was assigned to spiro-iminosugar 2 (Figure 3 ). The single crystal for 2 was developed in $\mathrm{CHCl}_{3} / \mathrm{MeOH}$, and $\mathrm{X}$-ray crystallographic analysis supported the ${ }^{1} C_{4}$ conformation (Figure 3 ).

The spiro-linked iminosugar $3 \mathrm{a}$ is symmetric. Therefore, $\mathrm{H} 1$ and $\mathrm{H} 5$ protons (both axial and equatorial) as well as $\mathrm{H} 2$ and 
(a)

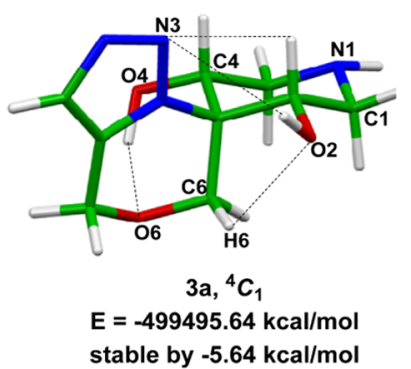

stable by $-5.64 \mathrm{kcal} / \mathrm{mol}$

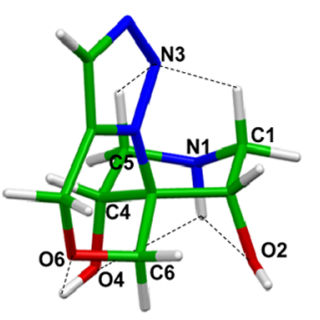

$3 \mathrm{a},{ }^{1} \mathrm{C}_{4}$

$E=-499490.0 \mathrm{kcal} / \mathrm{mol}$

(b)

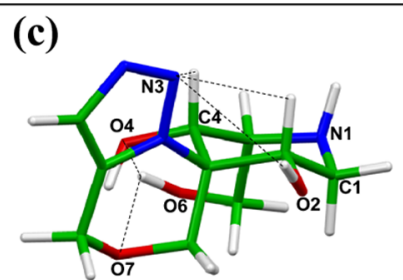

$4 a,{ }^{4} C_{1}$

$E=-571357.57 \mathrm{kcal} / \mathrm{mol}$

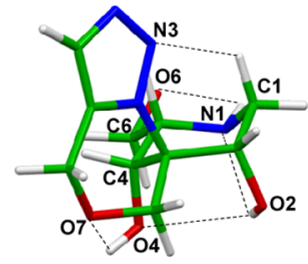

$4 a,{ }^{1} C_{4}$

$E=-571361.96 \mathrm{kcal} / \mathrm{mol}$ stable by $-4.39 \mathrm{kcal} / \mathrm{mol}$
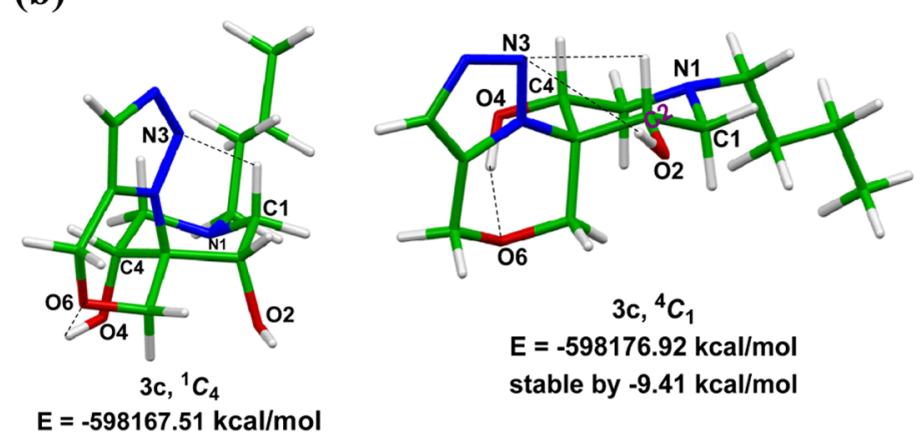

$3 \mathrm{c},{ }^{4} C_{1}$

$E=-598176.92 \mathrm{kcal} / \mathrm{mol}$ stable by $-9.41 \mathrm{kcal} / \mathrm{mol}$

(d)

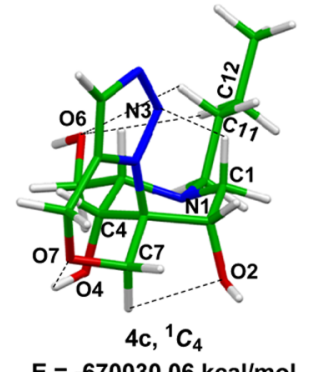

$E=-670036.97 \mathrm{kcal} / \mathrm{mol}$

stable by $-6.90 \mathrm{kcal} / \mathrm{mol}$

$E=-670030.06 \mathrm{kcal} / \mathrm{mol}$

Figure 4. Geometrically DFT-optimized conformations of 3a, 3c, 4a, and $4 c$ and their energies.

$\mathrm{H} 4$ protons are identical. The equivalent $\mathrm{H} 1 \mathrm{a}$ and $\mathrm{H} 5 \mathrm{a}$ showed dd at $\delta 2.84$ with $J=13.4$ and $10.8 \mathrm{~Hz}$. The large coupling constant of $10.8 \mathrm{~Hz}$ between $\mathrm{H} 1 \mathrm{a}$ and $\mathrm{H} 2$ or between $\mathrm{H} 5 \mathrm{a}$ and $\mathrm{H} 4$ requires axial orientation of both $\mathrm{H} 2$ and $\mathrm{H} 4$ protons with trans-relative stereochemistry, thus suggesting the ${ }^{4} C_{1}$ conformation to $\mathbf{3 a}$ (Figure 3). The single crystal of $\mathbf{3 a}$ (Figure 3) was obtained in $\mathrm{CHCl}_{3} / \mathrm{MeOH}$, and X-ray crystallographic study supported the ${ }^{4} C_{1}$ conformation. The $\mathrm{N}$-alkyl derivatives of $3 \mathbf{a}$, namely, $3 \mathbf{b}-\mathbf{g}$ also showed ${ }^{4} C_{1}$ conformation analogous to parent compound $3 \mathbf{a}$ on the basis of their nearly identical $J$ values (Figure 3 ).

In case of spiro-linked iminosugar 4a, the Hla (axial) proton appeared at $\delta 3.07$ as a dd (Figure 3) with $J=14.8$ and $3.3 \mathrm{~Hz}$ and H1e was observed at $\delta 3.60$ as dd with $J=14.4$ and $3.3 \mathrm{~Hz}$. Accordingly, $\mathrm{H} 2$ appeared at as a triplet with $J=3.3 \mathrm{~Hz}$. The small coupling constant value between $\mathrm{H} 1 \mathrm{a}$ and $\mathrm{H} 2$ requires equatorial orientation of $\mathrm{H} 2$ (cis-relative stereochemistry), thus accounting for the ${ }^{1} C_{4}$ conformation of compound $4 a$. This fact is further supported by $\mathrm{H} 4$, which appeared as a doublet at $\delta$ 4.11 with small $J_{4,5}=2.6 \mathrm{~Hz}$, indicating equatorial orientation of $\mathrm{H} 4$. We presume that the ${ }^{1} \mathrm{C}_{4}$ conformation is stabilized due to the equatorial orientation of $\mathrm{CH}_{2} \mathrm{OH}$ as well as intramolecular $\mathrm{H}$-bonding between the $\mathrm{C} 2$ and $\mathrm{C} 4-\mathrm{OH}$ groups, as shown in Figure 3. In case of $\mathrm{N}$-alkyl derivatives $4 \mathbf{b}-\mathbf{g}$, we noticed the change in conformation (Figure 3) as H1a appeared as dd with $J \approx 12.9$ and $\approx 8.0 \mathrm{~Hz}$. The large coupling constant between $\mathrm{H} 1 \mathrm{a}$ and $\mathrm{H} 2$ requires relative trans-diaxial orientation suggesting ${ }^{4} C_{1}$ conformation.

The conformational preferences were supported by the DFT calculations. Thus, DFT-optimized geometries of conformations ${ }^{1} C_{4} /{ }^{4} C_{1}$ for compounds $3 \mathbf{a}, 3 \mathbf{c}$, $4 \mathbf{a}$, and $4 \mathbf{c}$ were subjected for hydrogen-bonding interaction analysis (Table S1) and are represented in Figure $4 .^{c}$
As shown in Figure 4a, the adopted ${ }^{4} C_{1}$ conformation of $3 a$ that is stabilized by intramolecular $\mathrm{O} 6 \cdots \mathrm{H}-\mathrm{O} 4, \mathrm{~N} 3 \cdots \mathrm{H}-\mathrm{O} 2$, and $\mathrm{O} 2 \cdots \mathrm{H}-\mathrm{C} 6$ hydrogen-bonding interactions was found to be energetically more stable by $-5.64 \mathrm{kcal} / \mathrm{mol}$ over its ${ }^{1} C_{4}$ conformation. In ${ }^{4} C_{1}$ conformation, the $\mathrm{O} 6 \cdots \mathrm{H}-\mathrm{O} 4$ interaction was found to be strong as compared to ${ }^{1} C_{4}$ conformation. Further, the weak interactions between $\mathrm{N} 3 \cdots \mathrm{H}-\mathrm{C} 2$ and $\mathrm{N} 3 \cdots$ $\mathrm{H}-\mathrm{C} 4$ provided additional stability to ${ }^{4} C_{1}$ conformation. Similarly, N-butyl analogue $3 \mathrm{c}$ also adopted the same ${ }^{4} C_{1}$ conformation, which is stable by $-9.41 \mathrm{kcal} / \mathrm{mol}$ as compared to its ${ }^{1} C_{4}$ conformation (Figure $4 \mathrm{~b}$, Table S1). This conformation was stabilized by hydrogen-bonding interactions between $\mathrm{O} 6 \cdots \mathrm{H}-\mathrm{O} 4, \mathrm{~N} 3 \cdots \mathrm{H}-\mathrm{O} 2$, and $\mathrm{N} 3 \cdots \mathrm{H}-\mathrm{C} 2$.

In case of compound $4 \mathrm{a}$, the DFT-optimized ${ }^{1} \mathrm{C}_{4}$ conformation, which is stabilized by $\mathrm{O} 7 \cdots \mathrm{H}-\mathrm{O} 4, \mathrm{O} 4 \cdots \mathrm{H}-$ $\mathrm{O} 2$, O6 $\cdots \mathrm{H}-\mathrm{N} 1$, and $\mathrm{N} 1 \cdots \mathrm{H}-\mathrm{O} 2$ interactions (Figure $4 \mathrm{c}$ ), was found to be more stable by $-4.39 \mathrm{kcal} / \mathrm{mol}$ as compared to the ${ }^{4} C_{1}$ conformation. The preference of bulkier C6 hydroxy methylene group toward the equatorial orientation (that avoids 1,3-diaxial steric interactions) might be contributing in stability of ${ }^{1} C_{4}$ conformation by lowering its energy. However, the optimized geometry of $N$-butyl derivative $4 \mathrm{c}$ was adopted ${ }^{4} C_{1}$ conformation, which is more stable by $-6.90 \mathrm{kcal} / \mathrm{mol}$ over its ${ }^{1} C_{4}$ (Figure $4 \mathrm{~d}$ ). The preference of ${ }^{4} C_{1}$ conformation was supported by strong $\mathrm{H}$-bonding between $\mathrm{O} 7 \cdots \mathrm{H}-\mathrm{O} 4, \mathrm{O} 4 \cdots \mathrm{H}-$ $\mathrm{O} 6$, and $\mathrm{N} 3 \cdots \mathrm{H}-\mathrm{O} 2$ and by weak $\mathrm{N} 3 \cdots \mathrm{H}-\mathrm{C} 2, \mathrm{~N} 3 \cdots \mathrm{H}-\mathrm{C} 4$, and $\mathrm{O} 2 \cdots \mathrm{H}-\mathrm{C} 4$ interactions. This leads to axial orientation of hydroxy methylene group, which is stabilized by the $\mathrm{O} 4 \cdots \mathrm{H}-$ O6 interaction in $4 c$.

Biological Activities. Glycosidase Inhibitory Activity. The newly synthesized spiro-iminosugars $(\mathbf{1}, \mathbf{2}, \mathbf{3 a}-\mathbf{g}$, and $\mathbf{4 a - g})$ were evaluated for their inhibitory activity against a number of commercially available glycosidases, such as $\alpha$-glucosidase (rice) [E.C.3.2.1.20], $\beta$-glucosidase (rice) [E.C.3.2.1.21], $\alpha$ - 
Table 1. $\mathrm{IC}_{50}$ and $K_{\mathrm{i}}($ in $\mu \mathrm{M})$ Values for Synthesized Compounds and Standards Miglitol and DNJ

\begin{tabular}{|c|c|c|c|c|c|c|}
\hline compound & & $\alpha$-glucosidase (rice) & $\beta$-glucosidase (rice) & $\alpha$-galactosidase (bovine) & $\beta$-galactosidase (bovine) & $\alpha$-mannosidase (Jack bean) \\
\hline \multirow[t]{2}{*}{ miglitol } & $\mathrm{IC}_{50}$ & 0.100 & 342 & NI & NI & NI \\
\hline & $K_{\mathrm{i}}$ & 0.081 & 320 & NI & $\mathrm{NI}$ & NI \\
\hline \multirow[t]{2}{*}{$\mathrm{DNJ}$} & $\mathrm{IC}_{50}$ & 0.05 & 327 & 890 & NI & NI \\
\hline & $K_{\mathrm{i}}$ & 0.012 & 450 & 1030 & NI & NI \\
\hline \multirow[t]{2}{*}{1} & $\mathrm{IC}_{50}$ & 0.069 & 336 & 695 & NI & NI \\
\hline & $K_{\mathrm{i}}$ & 0.012 & 628 & 896 & $\mathrm{NI}$ & NI \\
\hline \multirow[t]{2}{*}{2} & $\mathrm{IC}_{50}$ & 0.159 & 428 & 993 & $\mathrm{NI}$ & NI \\
\hline & $K_{\mathrm{i}}$ & 0.129 & 456 & 932 & NI & NI \\
\hline \multirow[t]{2}{*}{$3 a$} & $\mathrm{IC}_{50}$ & 0.075 & 285 & 632 & NI & NI \\
\hline & $K_{\mathrm{i}}$ & 0.098 & 240 & 1300 & $\mathrm{NI}$ & NI \\
\hline \multirow[t]{2}{*}{$3 b$} & $\mathrm{IC}_{50}$ & 0.032 & 84 & 84 & 81 & 79 \\
\hline & $K_{\mathrm{i}}$ & 0.025 & 14 & 14 & 23 & 80 \\
\hline \multirow[t]{2}{*}{$3 c$} & $\mathrm{IC}_{50}$ & 0.033 & 89 & 73 & 81 & 66 \\
\hline & $K_{\mathrm{i}}$ & 0.028 & 59 & 58 & 33 & 90 \\
\hline \multirow[t]{2}{*}{$3 d$} & $\mathrm{IC}_{50}$ & 0.035 & 251 & 84 & 113 & 73 \\
\hline & $K_{\mathrm{i}}$ & 0.028 & 152 & 68 & 134 & 43 \\
\hline \multirow[t]{2}{*}{$3 e$} & $\mathrm{IC}_{50}$ & 0.037 & 286 & 86 & 73 & 91 \\
\hline & $K_{\mathrm{i}}$ & 0.022 & 191 & 75 & 68 & 56 \\
\hline \multirow[t]{2}{*}{$3 f$} & $\mathrm{IC}_{50}$ & 0.038 & 291 & 12 & 64 & 98 \\
\hline & $K_{\mathrm{i}}$ & 0.031 & 93 & 04 & 38 & 61 \\
\hline \multirow[t]{2}{*}{$3 g$} & $\mathrm{IC}_{50}$ & 0.049 & 286 & 88 & 86 & 101 \\
\hline & $K_{\mathrm{i}}$ & 0.042 & 135 & 71 & 38 & 95 \\
\hline \multirow[t]{2}{*}{$4 a$} & $\mathrm{IC}_{50}$ & 0.036 & 120 & 578 & NI & NI \\
\hline & $K_{\mathrm{i}}$ & 0.033 & 798 & 1650 & NI & NI \\
\hline \multirow[t]{2}{*}{$4 b$} & $\mathrm{IC}_{50}$ & 0.030 & 295 & 93 & 191 & 63 \\
\hline & $K_{\mathrm{i}}$ & 0.024 & 214 & 82 & 69 & 33 \\
\hline \multirow[t]{2}{*}{$4 c$} & $\mathrm{IC}_{50}$ & 0.032 & 298 & 86 & 58 & 74 \\
\hline & $K_{\mathrm{i}}$ & 0.025 & 171 & 58 & 39 & 65 \\
\hline \multirow[t]{2}{*}{$4 d$} & $\mathrm{IC}_{50}$ & 0.032 & 287 & 87 & 96 & 78 \\
\hline & $K_{\mathrm{i}}$ & 0.027 & 215 & 55 & 84 & 58 \\
\hline \multirow[t]{2}{*}{$4 e$} & $\mathrm{IC}_{50}$ & 0.032 & 241 & 82 & 89 & 91 \\
\hline & $K_{\mathrm{i}}$ & 0.026 & ND & 61 & 79 & 61 \\
\hline \multirow[t]{2}{*}{$4 f$} & $\mathrm{IC}_{50}$ & 0.037 & $>1000$ & 88 & 74 & 86 \\
\hline & $K_{\mathrm{i}}$ & 0.024 & ND & 67 & 52 & 58 \\
\hline \multirow[t]{2}{*}{$4 g$} & $\mathrm{IC}_{50}$ & 0.034 & $>1000$ & 87 & 76 & 68 \\
\hline & $K_{\mathrm{i}}$ & 0.019 & ND & 54 & 54 & 69 \\
\hline
\end{tabular}

galactosidase (bovine liver) [E.C.3.2.1.22], $\beta$-galactosidase (bovine liver, cytosolic) [E.C.3.2.1.23], and $\alpha$-mannosidase (Jack beans) [E.C.3.2.1.24], with reference to known standards, namely, miglitol ( $N$-hydroxyethyl 1-deoxynojirimycin, trade name Glycet) and 1-deoxynojirimycin (DNJ). The corresponding $\mathrm{IC}_{50}$ values and inhibition constants $\left(K_{\mathrm{i}}\right)$ were determined from Lineweaver-Burk plots (Figures S55-S59), and the results are summarized in Table 1 . The six-membered (piperidine) and seven-membered (azepine) iminosugars are known to be $\alpha$-glucosidase inhibitors among various glycosidases, and the same trend was noticed with $1,2,3 \mathbf{a}-\mathbf{g}$, and $4 a-g$ that showed good to potent inhibition of $\alpha$-glucosidase. In addition, compounds $1,2,3 \mathbf{a}-\mathbf{g}$, and $4 \mathbf{a}-\mathbf{g}$ were found to be selective inhibitors of $\alpha$-glucosidase (Table 1), wherein the spiro-iminosugar $2\left(\mathrm{IC}_{50}=0.159\right.$ and $\left.K_{\mathrm{i}}=0.129 \mu \mathrm{M}\right)$ was found to be a weak inhibitor of $\alpha$-glucosidase, whereas $4 \mathrm{a}\left(\mathrm{IC}_{50}\right.$ $=0.036$ and $K_{\mathrm{i}}=0.033 \mu \mathrm{M}$ ) was found to a better inhibitor of $\alpha$-glucosidase than miglitol $\left(\mathrm{IC}_{50}=0.1\right.$ and $\left.K_{\mathrm{i}}=0.081 \mu \mathrm{M}\right)$. This fact could be attributed to the synergetic effect of two pharmacophores, namely, iminosugar and 1,2,3-triazole (known to be $\alpha$-glucosidase inhibitor). ${ }^{29}$

From Table 1 , it is evident that the $\alpha$-glucosidase inhibitory activity of $\mathrm{N}$-alkylated iminosugars $3 \mathrm{~b}-\mathrm{g}$ and $4 \mathrm{~b}-\mathrm{g}$ was significantly improved as compared to their parent compounds $3 a$ and $4 a$, respectively. At the same time, N-alkylated compounds $\mathbf{3 b}-\mathbf{g} / \mathbf{4} \mathbf{b}-\mathbf{g}$ were found to inhibit other enzymes in a micromolar range (Table 1 ) and suggest fall in selectivity of enzyme inhibition for them in contrast to $\mathbf{3 a}$ and $\mathbf{4 a}$, respectively. Elongation of alkyl chain from ethyl to dodecyl, however, showed decrease in $\alpha$-glucosidase inhibition with each higher homologue of alkyl chain.

Antifungal Activity. The use of 1,2,3-triazole moiety in advanced antifungal drug designing provided a platform to synthesize new antifungal agents containing 1,2,3-triazole pharmacophore. ${ }^{30}$ In view of this, we have investigated the spiro-iminosugars $\mathbf{1}, \mathbf{2}, \mathbf{3 a}-\mathrm{g}$, and $\mathbf{4 a}-\mathrm{g}$ for their antifungal activities against $C$. albicans in comparison to a well-known marketed antifungal drug, namely, amphotericine $b$, recommended for infection of $C$. albicans (Table 2). The MIC value of $3 \mathrm{a}(0.85 \mu \mathrm{g} / \mathrm{mL})$ is found to be less than that of amphotericine $\mathrm{b}(1.25 \mu \mathrm{g} / \mathrm{mL})$, whereas the value of $\mathbf{4 a}$ $(0.025 \mu \mathrm{g} / \mathrm{mL})$ was found to be $\sim 50$ times higher active than that of amphotericine b. Compounds $1(2.5 \mu \mathrm{g} / \mathrm{mL})$ and 2 $(1.25 \mu \mathrm{g} / \mathrm{mL})$ are, respectively, either weak or comparatively active with the marketed drug. 
Table 2. Antifungal Activities of $1,2,3 a-g$, and $4 a-g^{a}$

\begin{tabular}{llclcl}
\multicolumn{1}{c}{ compound } & MIC & compound & MIC & compound & MIC \\
amphotericin b & 1.25 & $\mathbf{1}$ & 2.5 & $\mathbf{2}$ & 1.25 \\
$\mathbf{3 a}$ & 0.85 & $\mathbf{3 b}$ & $>1.25$ & $\mathbf{3 c}$ & $>2.5$ \\
$\mathbf{3 d}$ & $>2.5$ & $\mathbf{3 e}$ & $>2.5$ & $\mathbf{3 f}$ & $>1.25$ \\
$\mathbf{3 g}$ & 1.25 & $\mathbf{4 a}$ & 0.025 & $\mathbf{4 b}$ & $>1.25$ \\
$\mathbf{4 c}$ & 0.025 & $\mathbf{4 d}$ & 0.020 & $\mathbf{4 e}$ & $>1.25$ \\
$\mathbf{4 f}$ & $>1.25$ & $\mathbf{4 g}$ & $>1.25$ & &
\end{tabular}

${ }^{a}$ Minimum inhibition concentration (MIC) values in $\mu \mathrm{g} / \mathrm{mL}$.

Among $\mathrm{N}$-alkylated derivatives, compound 4c ( $\mathrm{MIC}=0.025$ $\mu \mathrm{g} / \mathrm{mL}$ ) was found to be comparably active to parent molecule 4a, whereas compound $4 \mathrm{~d}(\mathrm{MIC}=0.020 \mu \mathrm{g} / \mathrm{mL})$ showed higher activity than $\mathbf{4 a}$. The MIC values of compounds $3 \mathbf{b}-\mathbf{g}$ (Table 2) are higher than those of amphotericine $\mathrm{b}(1.25 \mu \mathrm{g} /$ $\mathrm{mL}$ ), whereas for $\mathbf{4 b}-\mathbf{g}$, various MIC values are found. Compounds $4 \mathrm{~b}$ and $4 \mathrm{e}-\mathrm{g}(\mathrm{MIC}>1.25 \mu \mathrm{g} / \mathrm{mL})$ are weakly or less active than 4a. Thus, all other $\mathrm{N}$-alkyl derivatives (except $\mathbf{4 b}$ and $4 \mathbf{c}$ ) were found to be less antifungal than their parent compounds. The confocal images of all screened compounds showed aggregation of the molecules at the fungal cell surface and exhibited cell wall disruption (Figure 5).

Molecular Docking Studies. Glycosidases and Ligand Interactions. The observed biological activities were supported by molecular docking studies. Thus, molecular interaction of inhibitor molecules with rice $\alpha$-glucosidase was analyzed by docking studies. Binding scores of synthesized spiro-iminosugars $(\mathbf{1}, \mathbf{2}, \mathbf{3} \mathbf{a}-\mathbf{g}$, and $\mathbf{4 a}-\mathbf{g})$ are illustrated in Table S3 and binding poses on the active site of $\alpha$-glucosidase (rice) enzyme are shown in Figure 6. Corroboration of binding free energies with the inhibition kinetic studies indicated that among synthesized compounds, molecules 1, 2, 3a, and 4a are potent competitive inhibitors of rice $\alpha$-glucosidase. All screened molecules with their respective conformations $\left({ }^{1} C_{4}\right.$ or ${ }^{4} C_{1}$ for piperidine iminosugars) form favorable contacts with binding pocket of $\alpha$-glucosidase. Analysis of polar contacts and other weak interactions (electrostatic and $\pi$-interaction) of these compounds showed that the higher binding affinity is presumably attributed to the formation of higher number of stable intermolecular hydrogen bonds between the reactive group of compounds and ASP204, ILE205, SER469, ARG473, ASN477, and LYS478 at the binding site of the enzyme (Figure 6 ). However, several $\pi$-alkyl interactions observed between ligand aromatic ring and interacting residues of enzyme assist polar interaction. In case of $\mathrm{N}$-alkyl derivatives $3 \mathbf{b}-\mathbf{g}$ and $\mathbf{4 b}-\mathbf{g}$, it has been observed that binding of these ligands with enzyme was unfavorable as compared to the parental compounds (Table S3). This suggests that addition of $\mathrm{N}$-alkyl chain to 3 a and $4 \mathbf{a}$ reduces the number of interactions with binding site

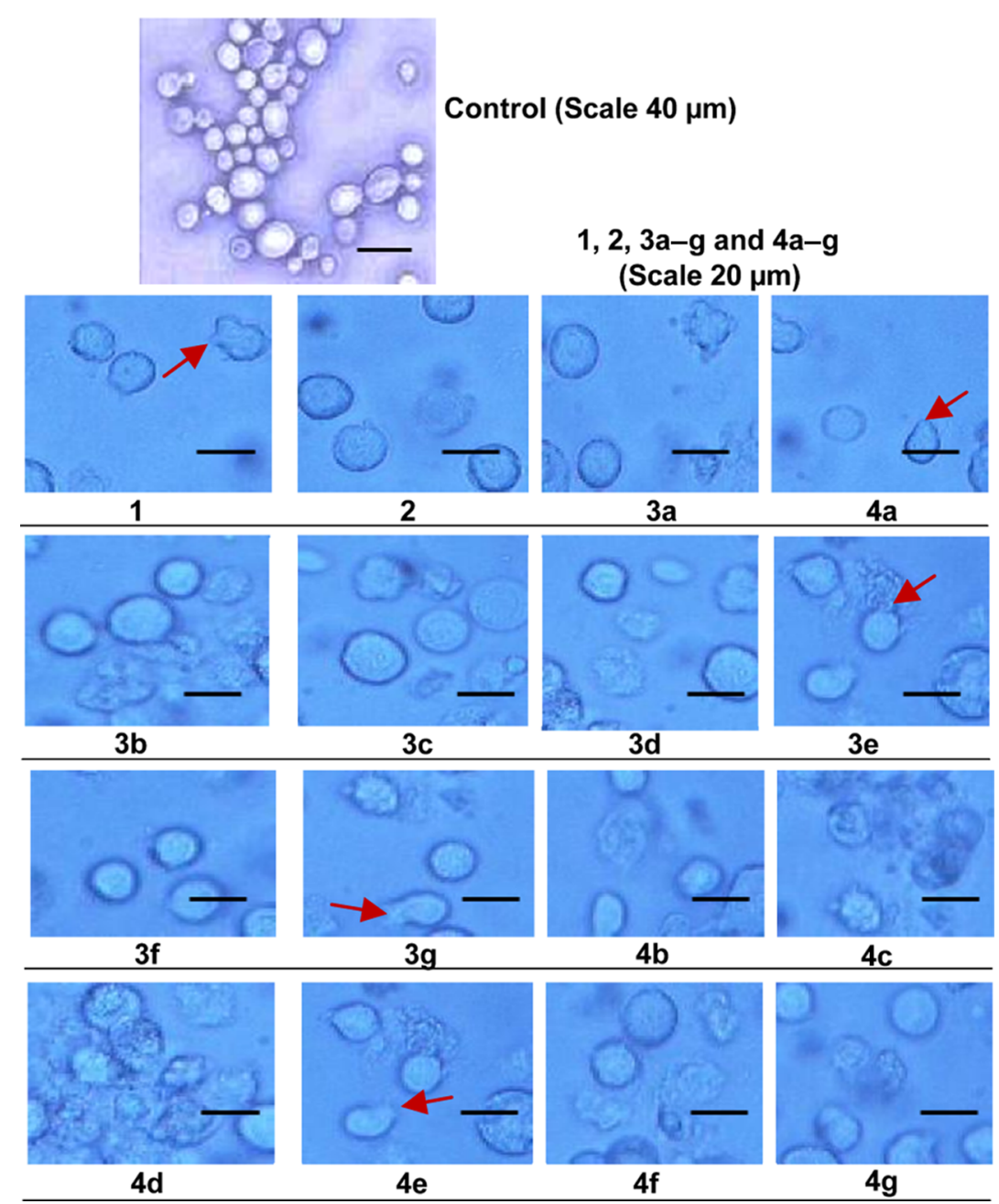

Figure 5. Confocal images of compounds $1,2,3 a-g$, and $4 a-g$ with yeast cell. The red arrows show site of cell wall disruption. 


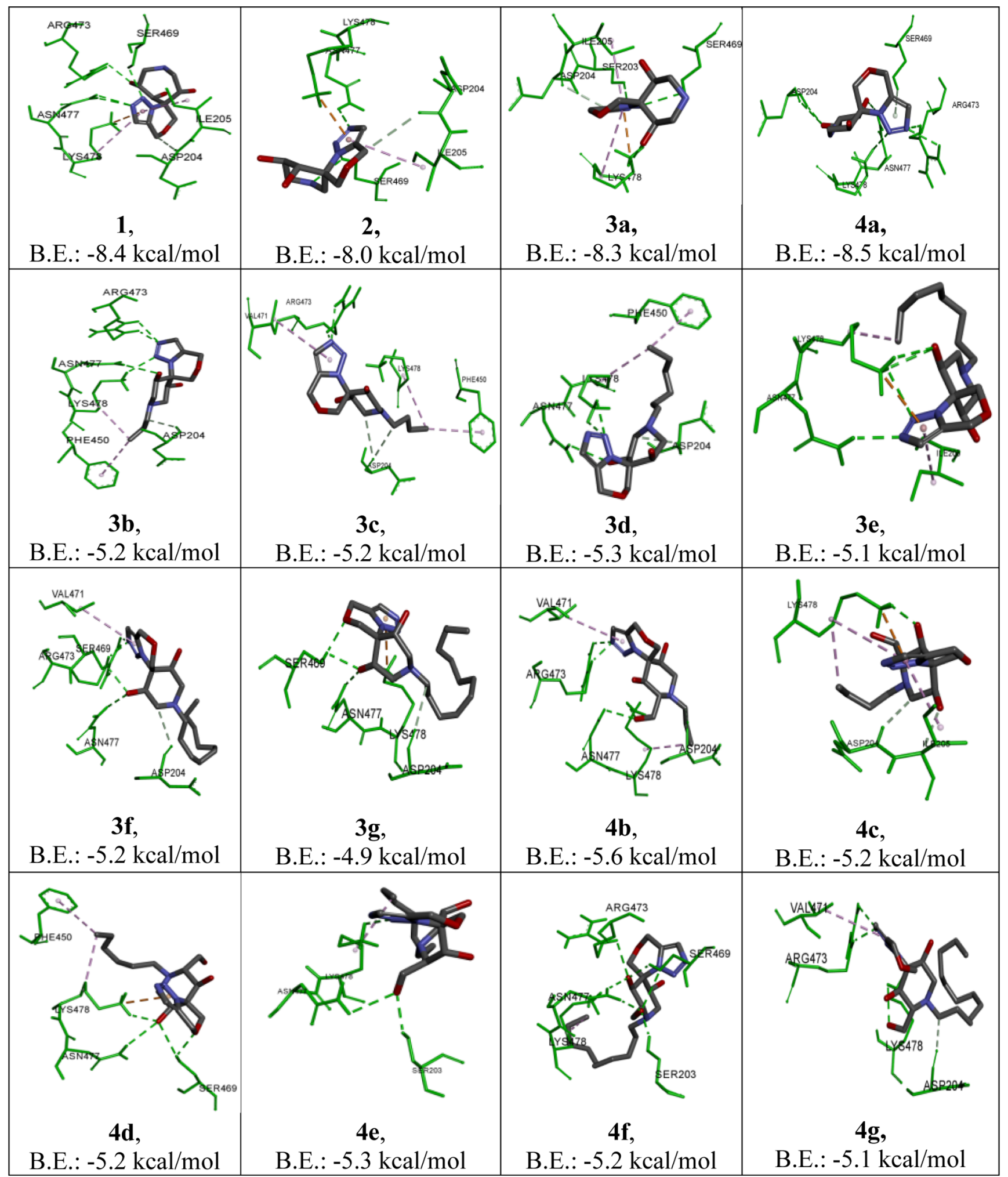

Figure 6. Docking images and binding energies (B.E.) of iminosugars with $\alpha$-glucosidase (rice).

residues. As a result, changes in functional group lead to differential interactions with binding pocket of enzyme. Minute deviation in biological activity with respect to molecular docking observations might be due to variations in ligand conformation, in vitro assay condition, solvation of ligand, and ligand charge state.
Molecular Docking Studies for Antifungal Activity. Antifungal potential of spiro-iminosugars (1, 2, 3a, 4a, 4c, and 4d) was analyzed using a docking simulation in relation with amphotericine $b$ as a positive control. The positive binding energy $(10.5 \mathrm{kcal} / \mathrm{mol})$ for amphotericine $b$ suggests that its interaction with ergosterol is predominated by unfavorable interaction over favorable contacts (Figure 7). Analogously, we 


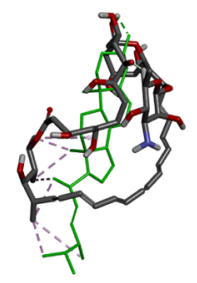

amphotericin b B. E. $=10.5$

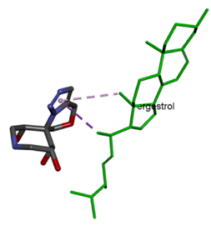

1

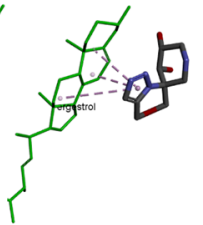

2

B. E. $=-1.9$

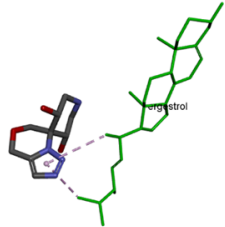

$3 a$

B. $\mathrm{E}^{\mathbf{3 a}}=-1.8$

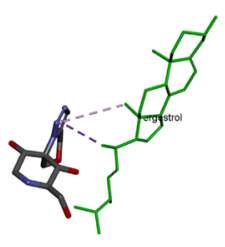

$4 a$

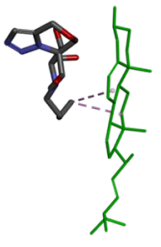

$4 c$

B. $\mathrm{E} .=-2.2$

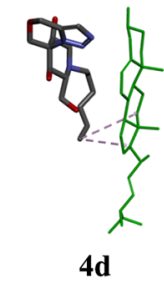

B. E. $=-2.6$

Figure 7. Docking of 1, 2, 3a, 4a, 4c, and 4d with ergosterol component of cell wall of C. albicans (binding energy (B.E.) is in kcal/ mol).

have predicted binding of spiro-iminosugars with ergosterol, a component of fungal cell membranes, which might result in the disruption of the fungal cell wall and lead to fungal cell death. Compounds 1, 2, and 3a showed approximately equal binding energies $(-1.9,-1.8$, and $-1.8 \mathrm{kcal} / \mathrm{mol})$ with ergosterol, whereas the highest binding energy of $-2.2 \mathrm{kcal} / \mathrm{mol}$ was noticed for compound 4a. All compounds exhibited $\pi$-alkyl interaction as shown in Figure 7. The $\mathrm{N}$-alkylated derivatives $4 \mathrm{c}$ (B.E. $-2.4 \mathrm{kcal} / \mathrm{mol}$ ) and 4d (B.E. $-2.6 \mathrm{kcal} / \mathrm{mol}$ ) (Figure 7) exhibit strong binding with ergosterol as compared to their parent compound 4a. This increase in binding energy in derivatives $\mathbf{4 c}$ and $\mathbf{4 d}$ than their parent iminosugar $\mathbf{4 a}$ is in agreement with the in vitro antifungal data (Table 2).

\section{CONCLUSIONS}

In conclusion, the AAC reaction of 3-O-propargyl-3-azido-Dglucofuranose derivative (IXd) gave adduct $\mathbf{5}$ that was used as a common intermediate, by judicious manipulation of the 1,2and 5,6-O-isopropylidene groups, in the synthesis of library of spiro-iminosugars $(\mathbf{1}, \mathbf{2}, \mathbf{3} \mathbf{a}-\mathbf{g}$, and $\mathbf{4 a}-\mathbf{g})$ linked with the $1,2,3-$ triazole-fused morpholine. The presence of two pharmacophores, such as iminosugar and triazole, showed dual biological activity. In addition, the synergetic effect of two pharmacophores led to augmentation of the glycosidase inhibitory as well as antifungal activity. Among 16 examples, the spiroiminosugars $3 \mathbf{a}$ and $4 \mathbf{a}$ were found to be more potent inhibitors of $\alpha$-glucosidase than miglitol as well as showed high antifungal activity against $C$. albicans than amphotericin b. The $\mathrm{N}$-alkyl derivatives showed increase of $\alpha$-glucosidase inhibition and enhancement of antifungal activity as compared to their respective parent iminosugar. Thus, the synthesized spiroiminosugars may open a new era of potential chimeric drugs in comorbidity treatments.

\section{EXPERIMENTAL SECTION}

General Methods for Synthesis. Melting points were recorded using Thomas-Hoover melting point apparatus and are uncorrected. IR spectra were recorded with an FTIR spectroscope as a thin film or using $\mathrm{KBr}$ pellets and are expressed in $\mathrm{cm}^{-1}$. ${ }^{1} \mathrm{H} \mathrm{NMR}(300,400$, or $500 \mathrm{MHz})$ and ${ }^{13} \mathrm{C}$

NMR (100 or $125 \mathrm{MHz}$ ) spectra were recorded using $\mathrm{CDCl}_{3}$, $\mathrm{CD}_{3} \mathrm{OD}$, or $\mathrm{D}_{2} \mathrm{O}$ as solvent(s). Chemical shifts were reported in $\delta$ unit (parts per million) with reference to TMS as an internal standard, and coupling constant $(J)$ values were given in Hertz. Optical rotations were measured using a polarimeter at $22{ }^{\circ} \mathrm{C}$. High-resolution mass spectra (HRMS) were obtained in positive-ion electrospray ionization (ESI) mode using timeof-flight analyzer. Thin-layer chromatography was performed on precoated plates $(0.25 \mathrm{~mm}$, silica gel $60 \mathrm{~F} 254)$. Column chromatography was carried out with silica gel (100-200 mesh). Reactions were carried out in oven-dried glassware under dry $\mathrm{N}_{2}$ atmosphere. Methanol, dichloromethane, and THF were purified and dried according to reported methods. Petroleum ether (PE) was a distillation fraction between 40 and $60{ }^{\circ} \mathrm{C}$. The $10 \% \mathrm{Pd} / \mathrm{C}$ was purchased from Aldrich. After neutralization, workup involves washing of combined organic layer with water and brine, drying over anhydrous sodium sulfate, and evaporating the solvent under reduced pressure, followed by vacuum drying.

Synthesis of 6. Compound 5 (2.5 g, $7.07 \mathrm{mmol})$ was dissolved in $60 \%$ aq $\mathrm{AcOH}(15 \mathrm{~mL})$ and heated at $60{ }^{\circ} \mathrm{C}$ for 3 h. RM was directly concentrated in a rotary evaporator under vacuum, and the thick residue obtained was dissolved in ethyl acetate (EtOAc) and washed with saturated aq $\mathrm{NaHCO}_{3}$ and distilled water. The organic layer was evaporated to dryness to give a thick syrup. Column purification of the syrup was done with eluting of a 7:3 mixture of ethyl acetate and petroleum ether to ease the synthesis of $6(2.04 \mathrm{~g}, 92 \%)$ as a solid. $R_{f}=$ 0.15, EtOAc; $\mathrm{mp}=66-68{ }^{\circ} \mathrm{C} ;[\alpha]_{\mathrm{D}}^{22}=-21.7$ (c 0.108, methanol); IR (KBr, $\left.\nu, \mathrm{cm}^{-1}\right)$ 3433, 2987, 2937, 1639, 1554, $1458,1379,1091,869,732 ;{ }^{1} \mathrm{H}$ NMR (300 $\left.\mathrm{MHz}_{1} \mathrm{CDCl}_{3}\right) \delta$ $7.56(\mathrm{~s}, 1 \mathrm{H}), 6.26(\mathrm{~d}, J=3.6 \mathrm{~Hz}, 1 \mathrm{H}), 4.98\left(\mathrm{AB}_{\mathrm{q}}, J=15.1 \mathrm{~Hz}\right.$, $2 \mathrm{H}), 4.65(\mathrm{~d}, J=3.6 \mathrm{~Hz}, 1 \mathrm{H}), 4.39\left(\mathrm{AB}_{\mathrm{q}}, J=12.6 \mathrm{~Hz}, 2 \mathrm{H}\right), 4.28$ $(\mathrm{d}, J=8.8 \mathrm{~Hz}, 1 \mathrm{H}), 3.74(\mathrm{dd}, J=11.6,3.2 \mathrm{~Hz}, 1 \mathrm{H}), 3.64(\mathrm{dd}, J$ = 11.6, $5.1 \mathrm{~Hz}, 1 \mathrm{H}$ ), 3.12 (ddd, $J=8.8,5.1,3.2 \mathrm{~Hz}, 1 \mathrm{H}$ ), 1.60 (s, 3H), 1.35 (s, 3H); ${ }^{13} \mathrm{C}$ NMR (125 MHz, $\left.\mathrm{CDCl}_{3}\right) \delta 131.6$, 128.3, 113.5, 105.7, 85.2, 81.1, 69.9, 68.9, 65.9, 64.1, 62.7, 26.9, 26.5; HRMS calculated for $\mathrm{C}_{13} \mathrm{H}_{19} \mathrm{~N}_{3} \mathrm{O}_{6} \mathrm{Na}[\mathrm{M}+\mathrm{Na}]^{+}$ 336.1169, Found: 336.1167.

Synthesis of 7. Compound $6(0.800 \mathrm{~g}, 2.55 \mathrm{mmol})$ was dissolved in dry DCM $(10 \mathrm{~mL})$, to which $\mathrm{Bu}_{2} \mathrm{SnO}(0.063 \mathrm{~g}$, $10 \% \mathrm{~mol}$ ) was added and stirred for $10 \mathrm{~min}$, followed by pinchwise addition of $\mathrm{TsCl}(0.535 \mathrm{~g}, 2.81 \mathrm{mmol})$ and dropwise addition of TEA (1.07 mL, $7.66 \mathrm{mmol})$. Reactions were maintained at RT for $1 \mathrm{~h}$ and then quenched by $1 \mathrm{M}$ aq $\mathrm{HCl}$ solution and extracted by dichloromethane $(2 \times 10 \mathrm{~mL})$. The dichloromethane layer was concentrated, and the obtained thick residue was purified by column chromatography using EtOAc/PE (3:2) as mobile phase $7(1.16 \mathrm{~g}, 97 \%)$ observed as a white solid. $R_{f}=0.56$, EtOAc/PE $(4: 1) ; \mathrm{mp}=86-88{ }^{\circ} \mathrm{C}$; $[\alpha]_{\mathrm{D}}{ }^{22}=-23.2$ (c 0.102, methanol); IR $\left(\mathrm{KBr}, \nu, \mathrm{cm}^{-1}\right)$ 3433, 2985, 2933, 1597, 1494, 1452, 1357, 1176, 1095, 985, 819, 667, 553; ${ }^{1} \mathrm{H}$ NMR $\left(500 \mathrm{MHz}, \mathrm{CDCl}_{3}\right) \delta 7.75(\mathrm{~d}, J=8.1 \mathrm{~Hz}, 2 \mathrm{H})$, $7.53(\mathrm{~s}, 1 \mathrm{H}), 7.33(\mathrm{~d}, J=8.1 \mathrm{~Hz}, 2 \mathrm{H}), 6.16(\mathrm{~d}, J=3.5 \mathrm{~Hz}, 1 \mathrm{H})$, $4.94(\mathrm{~s}, 2 \mathrm{H}), 4.56(\mathrm{~d}, J=3.5 \mathrm{~Hz}, 1 \mathrm{H}), 4.38\left(\mathrm{AB}_{\mathrm{q}}, J=12.6 \mathrm{~Hz}\right.$, $2 \mathrm{H}), 4.22(\mathrm{~d}, J=8.9 \mathrm{~Hz}, 1 \mathrm{H}), 4.15(\mathrm{dd}, J=10.4,2.4 \mathrm{~Hz}, 1 \mathrm{H})$, 4.06 (dd, $J=10.4,5.8 \mathrm{~Hz}, 1 \mathrm{H}), 3.42$ (ddd, $J=10.4 .5 .8,2.4 \mathrm{~Hz}$, $1 \mathrm{H}), 2.44(\mathrm{~s}, 3 \mathrm{H}), 1.57$ (s, 3H), $1.34(\mathrm{~s}, 3 \mathrm{H}) .{ }^{13} \mathrm{C}$ NMR $(125$ $\left.\mathrm{MHz} \mathrm{CDCl}_{3}\right) \delta 145.0,132.4,131.5,129.9$ (2C), 128.4, 128.0 (2C), 113.7, 105.8, 85.2, 80.4, 71.8, 69.7, 67.0, 65.9, 62.7, 27.1, 26.5, 21.7; HRMS calculated for $\mathrm{C}_{20} \mathrm{H}_{25} \mathrm{~N}_{3} \mathrm{O}_{8} \mathrm{SNa}[\mathrm{M}+\mathrm{Na}]^{+}$ 490.1255, Found: 490.1254. 
Synthesis of 8. Under $\mathrm{N}_{2}$ atmosphere, into a mixture of 7 (1.0 g, $2.14 \mathrm{mmol}), \mathrm{NaN}_{3}(0.166 \mathrm{~g}, 2.57 \mathrm{mmol})$, and TABI $(0.079 \mathrm{~g}, 10 \% \mathrm{~mol})$, dry DMF $(10 \mathrm{~mL})$ was added and heated to $95{ }^{\circ} \mathrm{C}$ for $3 \mathrm{~h}$. $\mathrm{RM}$ was concentrated directly, water $(5 \mathrm{~mL})$ was added, and extraction was carried out by EtOAc $(2 \times 10$ $\mathrm{mL})$. A thick residue was obtained, which was further purified by EtOAc/PE (3:2) as mobile phase for column chromatography. A white solid 8 was observed $(0.644 \mathrm{~g}, 89 \%) . R_{f}=0.65$, EtOAc/PE (4:1); mp $=151-153{ }^{\circ} \mathrm{C} ;[\alpha]_{\mathrm{D}}^{22}=-32.0(c$ 0.104, methanol); IR (KBr, $\nu, \mathrm{cm}^{-1}$ ) 3400, 2989, 2935, 2104, 1664, 1440, 1381, 1220, 1093, 929, 869, 771, 553; ${ }^{1} \mathrm{H}$ NMR (500 $\left.\mathrm{MHz} \mathrm{CDCl}_{3}\right) \delta 7.53(\mathrm{~s}, 1 \mathrm{H}), 6.23(\mathrm{~d}, J=3.5 \mathrm{~Hz}, 1 \mathrm{H}), 5.03(\mathrm{~d}$, $J=15.2 \mathrm{~Hz}, 1 \mathrm{H}), 4.93(\mathrm{~d}, J=15.2 \mathrm{~Hz}, 1 \mathrm{H}), 4.65(\mathrm{~d}, J=3.5 \mathrm{~Hz}$, $1 \mathrm{H}), 4.43(\mathrm{~d}, J=12.7 \mathrm{~Hz}, 1 \mathrm{H}), 4.33(\mathrm{~d}, J=12.7 \mathrm{~Hz}, 1 \mathrm{H}), 4.29$ $(\mathrm{d}, J=8.5 \mathrm{~Hz}, 1 \mathrm{H}), 3.46(\mathrm{dd}, J=10.5,3.2 \mathrm{~Hz}, 1 \mathrm{H}), 3.42(\mathrm{dd}, J$ $=10.5,5.2 \mathrm{~Hz}, 1 \mathrm{H}) 3.17(\mathrm{ddd}, J=8.5,5.2,3.2 \mathrm{~Hz}, 1 \mathrm{H}), 1.60(\mathrm{~s}$, $3 \mathrm{H}), 1.35(\mathrm{~s}, 3 \mathrm{H}) .{ }^{13} \mathrm{C} \mathrm{NMR}\left(125 \mathrm{MHz}, \mathrm{CDCl}_{3}\right) \delta 131.0$, 128.4, 113.8, 105.6, 85.4, 82.1, 69.6, 68.0, 66.4, 62.8, 54.0, 27.0, 26.5; HRMS calculated for $\mathrm{C}_{13} \mathrm{H}_{18} \mathrm{~N}_{6} \mathrm{O}_{5} \mathrm{Na}[\mathrm{M}+\mathrm{Na}]^{+}$ 361.1231, Found: 361.1237.

Synthesis of 1. To compound 8 ( $200 \mathrm{mg}, 0.591 \mathrm{mmol}$ ), $75 \%$ aq TFA ( $5 \mathrm{~mL}$, precooled to $0{ }^{\circ} \mathrm{C}$ ) was added and stirred for 3 h. After concentration under vacuum, saturated aq $\mathrm{NaHCO}_{3}(5$ $\mathrm{mL})$ was added and extracted with EtOAc $(2 \times 5 \mathrm{~mL})$. The organic layer was filtered through a 60-120 mesh silica bed with eluting EtOAc. A thick residue was observed on concentration, which was directly dissolved in distilled methanol $(5 \mathrm{~mL})$ and hydrogenated using $10 \% \mathrm{Pd} / \mathrm{C}$ (catalytic) at RT and 80 psi pressure of $\mathrm{H}_{2}$ for $24 \mathrm{~h}$ and filtered through a celite bed. $\mathrm{MeOH}$ was concentrated and purified by column chromatography to obtain a syrup with $\mathrm{MeOH} / \mathrm{CHCl}_{3}$ (1:4) as mobile phase. Amorphous solid (0.107 g, $71 \%$ over two steps) of 1 was observed. $R_{f}=0.50, \mathrm{MeOH} /$ $\mathrm{CHCl}_{3}(1: 4) ; \mathrm{mp}=235{ }^{\circ} \mathrm{C}\left(\mathrm{dec}\right.$.); $[\alpha]_{\mathrm{D}}^{22}=-42.8$ (c 0.101, methanol); IR (KBr, $\left.\nu, \mathrm{cm}^{-1}\right)$; 2968, 2106, 1639, 1450, 1377, 1217, 1166, 1095, 916, 868, 748, 700; ${ }^{1} \mathrm{H}$ NMR (500 MHz, $\left.\mathrm{D}_{2} \mathrm{O}\right) \delta 7.60(\mathrm{~s}, 1 \mathrm{H}), 4.93\left(\mathrm{AB}_{\mathrm{q}}, J=15.8 \mathrm{~Hz}, 2 \mathrm{H}\right), 4.52(\mathrm{ddd}, J$ $=8.1,3.4,1.7 \mathrm{~Hz}, 1 \mathrm{H}), 4.47(\mathrm{dd}, J=8.1,2.4 \mathrm{~Hz}, 1 \mathrm{H}), 4.47(\mathrm{~d}, J$ $=8.1,2.5 \mathrm{~Hz}, 1 \mathrm{H}), 4.43(\mathrm{~d}, J=1.7 \mathrm{~Hz}, 1 \mathrm{H}), 4.39(\mathrm{~d}, J=12.8$ $\mathrm{Hz}, 1 \mathrm{H}), 4.32(\mathrm{~d}, J=12.8 \mathrm{~Hz}, 1 \mathrm{H}), 3.70(\mathrm{dd}, J=14.2,2.5 \mathrm{~Hz}$, $1 \mathrm{H}), 3.52-3.38(\mathrm{~m}, 3 \mathrm{H}) ;{ }^{13} \mathrm{C}$ NMR $\left(125 \mathrm{MHz}, \mathrm{D}_{2} \mathrm{O}\right) \delta 133.2$, 128.8, 75.1, 68.6, 67.1, 66.3, 65.9, 62.0, 46.5, 45.7; HRMS calculated for $\mathrm{C}_{10} \mathrm{H}_{17} \mathrm{~N}_{4} \mathrm{O}_{4}[\mathrm{M}+\mathrm{H}]^{+}$257.1249, Found: 257.1255 .

Synthesis of 9. Compound $8(0.300 \mathrm{~g}, 0.886 \mathrm{mmol})$ in THF $(5 \mathrm{~mL})$ was added dropwise to a precooled $\left(0{ }^{\circ} \mathrm{C}\right)$ suspension of $\mathrm{NaH}(0.042 \mathrm{~g}, 1.06 \mathrm{mmol})$ in THF $(5 \mathrm{~mL})$, followed by drowise addition of $\mathrm{BnBr}(0.120 \mathrm{~mL}, 0.975 \mathrm{mmol})$. The reaction was maintained initially at $0{ }^{\circ} \mathrm{C}$ for $30 \mathrm{~min}$ and then at RT for $2.5 \mathrm{~h}$. The reaction was quenched with saturated aq ammonium chloride, extracted with EtOAc $(2 \times 5 \mathrm{~mL})$, and concentrated in vacuo at reduced pressure, which gave a thick residue. Purification of this residue was done by column chromatography using EtOAc/PE (2:3) as mobile phase. A white solid $9(0.284 \mathrm{~g}, 75 \%)$ was observed. $R_{f}=0.40 \mathrm{EtOAc} / \mathrm{PE}$ $(2: 3) ; \mathrm{mp}=108-110^{\circ} \mathrm{C} ;[\alpha]_{\mathrm{D}}{ }^{22}=-80.6$ (c 0.105, methanol); IR $\left(\mathrm{KBr}, \nu, \mathrm{cm}^{-1}\right) ; 2968,2935,2106,1550,1450,1494,1095$, 1018, 868, 748; ${ }^{1} \mathrm{H}$ NMR (500 MHz, $\left.\mathrm{CDCl}_{3}\right) \delta 7.55(\mathrm{~s}, 1 \mathrm{H})$, $7.35-7.29(\mathrm{~m}, 3 \mathrm{H}), 7.07(\mathrm{dd}, J=6.3,2.9 \mathrm{~Hz}, 2 \mathrm{H}), 6.21(\mathrm{~d}, J=$ $3.4 \mathrm{~Hz}, 1 \mathrm{H}), 4.83(\mathrm{~d}, J=14.8 \mathrm{~Hz}, 1 \mathrm{H}), 4.57(\mathrm{~d}, J=12.1 \mathrm{~Hz}$, $1 \mathrm{H}), 4.45$ (d, $J=10.8 \mathrm{~Hz}, 1 \mathrm{H}), 4.42$ (d, $J=3.4 \mathrm{~Hz}, 1 \mathrm{H}), 4.38$ $(\mathrm{d}, J=8.9 \mathrm{~Hz}, 1 \mathrm{H}), 4.12(\mathrm{~d}, J=14.8 \mathrm{~Hz}, 1 \mathrm{H}), 4.05$ (d, $J=12.1$ $\mathrm{Hz}, 1 \mathrm{H}), 3.85(\mathrm{dt}, J=8.9,2.8 \mathrm{~Hz}, 1 \mathrm{H}), 3.73(\mathrm{dd}, J=13.5,2.8$
$\mathrm{Hz}, 1 \mathrm{H}), 3.58(\mathrm{~d}, J=10.8 \mathrm{~Hz}, 1 \mathrm{H}), 3.50(\mathrm{dd}, J=13.5,2.8 \mathrm{~Hz}$ $1 \mathrm{H}), 1.62(\mathrm{~s}, 3 \mathrm{H}), 1.37(\mathrm{~s}, 3 \mathrm{H}) ;{ }^{13} \mathrm{C} \mathrm{NMR}\left(125 \mathrm{MHz} \mathrm{CDCl}_{3}\right)$ $\delta 136.6,132.0,128.6(2 \mathrm{C}), 128.5,128.2,128.0(2 \mathrm{C}), 113.8$, 105.9, 85.4, 77.8, 71.9, 70.0, 65.6, 62.4, 50.4, 27.4, 26.8; HRMS calculated for $\mathrm{C}_{20} \mathrm{H}_{24} \mathrm{~N}_{6} \mathrm{O}_{5} \mathrm{Na}[\mathrm{M}+\mathrm{Na}]^{+}$451.1705, Found: 451.1711.

Synthesis of 2. Compound $9(0.200 \mathrm{~g}, 0.591 \mathrm{mmol})$ was dissolved in $75 \%$ aq TFA ( $5 \mathrm{~mL}$, precooled to $\left.0{ }^{\circ} \mathrm{C}\right)$, stirred for $3 \mathrm{~h}$, and concentrated under vacuum. EtOAc $(5 \mathrm{~mL})$ was added and organic layer was washed with saturated aq $\mathrm{NaHCO}_{3}$. The EtOAc layer was filtered through a 60-120 mesh silica bed with eluting more EtOAc and concentrated. The thick residue obtained was directly dissolved in acetone/water $(8: 2,15 \mathrm{~mL})$ and cooled to $0{ }^{\circ} \mathrm{C}$. $\mathrm{NaIO}_{4}(0.573 \mathrm{~g}, 2.68 \mathrm{mmol})$ was pinchwise added to this mixture over $30 \mathrm{~min}$, and the reaction was maintained at $0{ }^{\circ} \mathrm{C}$ for $1 \mathrm{~h}$ and then at RT for another $1 \mathrm{~h}$. The reaction was quenched by cooling to $0^{\circ} \mathrm{C}$ and adding ethylene glycol and then concentrated on a rotary evaporator. Water was added and extracted twice by EtOAc $(6 \times 5 \mathrm{~mL}$ each $)$. A concentrated and thick residue obtained was directly dissolved in $\mathrm{MeOH}(5 \mathrm{~mL})$ and hydrogenated using $10 \% \mathrm{Pd} / \mathrm{C}$ (catalytic) and stirred at 120 psi pressure for $30 \mathrm{~h}$. RM was filtered through celite, concentrated, and purified by $\mathrm{MeOH} /$ $\mathrm{CHCl}_{3}$ (1:4) as mobile phase. Compound 2 was obtained as a white solid ( $0.071 \mathrm{~g}, 68 \%$ over two steps). $R_{f}=0.54, \mathrm{MeOH} /$ $\mathrm{CHCl}_{3}(1: 4) ; \mathrm{mp}=185-187{ }^{\circ} \mathrm{C} ;[\alpha]_{\mathrm{D}}{ }^{22}=-78.5$ (c 0.101, methanol); IR (KBr, $\left.\nu, \mathrm{cm}^{-1}\right)$; 3308, 2928, 1674, 1450, 1246, 1093, 833, 758; ${ }^{1} \mathrm{H}$ NMR (500 MHz, $\left.\mathrm{D}_{2} \mathrm{O}, 72{ }^{\circ} \mathrm{C}\right) \delta 7.67(\mathrm{~s}$, $1 \mathrm{H}), 5.08(\mathrm{~d}, J=15.0 \mathrm{~Hz}, 1 \mathrm{H}), 4.90(\mathrm{~d}, J=15.0 \mathrm{~Hz}, 1 \mathrm{H}), 4.72$ $(\mathrm{d}, J=3.2 \mathrm{~Hz}, 1 \mathrm{H}), 4.53(\mathrm{~d}, J=13.0 \mathrm{~Hz}, 1 \mathrm{H}), 4.20(\mathrm{bs}, 1 \mathrm{H})$, 4.19 (d, $J=13.0 \mathrm{~Hz}, 1 \mathrm{H}), 3.32$ (d, $J=13.8 \mathrm{~Hz}, 1 \mathrm{H}), 3.10$ (dd, $J$ $=14.4,1.5 \mathrm{~Hz}, 1 \mathrm{H}) 2.97(\mathrm{dd}, J=14.4,2.0 \mathrm{~Hz}, 1 \mathrm{H}), 2.93(\mathrm{~d}, J=$ $13.8 \mathrm{~Hz}, 1 \mathrm{H}) ;{ }^{13} \mathrm{C}$ NMR (125 MHz, $\left.\mathrm{D}_{2} \mathrm{O}\right) \delta 133.5,128.7,71.3$, 68.1, 64.8, 63.4, 61.8, 50.0, 48.5; DEPT-135, down (48.5, 50.0, $61.8,64.8)$, up $(68.2,71.3,128.8)$; HRMS calculated for $\mathrm{C}_{9} \mathrm{H}_{15} \mathrm{~N}_{4} \mathrm{O}_{3}[\mathrm{M}+\mathrm{H}]^{+}$227.1144, Found: 227.1142.

Synthesis of 10 . Acetone/water $(8: 2,15 \mathrm{~mL})$ was added to $6(0.700 \mathrm{~g}, 2.23 \mathrm{mmol})$ and cooled to $0{ }^{\circ} \mathrm{C} . \mathrm{NaIO}_{4}(0.573 \mathrm{~g}$, $2.68 \mathrm{mmol}$ ) was added pinchwise to this mixture over $30 \mathrm{~min}$ and stirred at $0{ }^{\circ} \mathrm{C}$ for $1 \mathrm{~h}$ and then at RT for another $1 \mathrm{~h}$. RM was cooled to $0{ }^{\circ} \mathrm{C}$ and ethylene glycol was added to quench the reaction and then RM was concentrated on a rotary evaporator. Water $(5 \mathrm{~mL})$ was added and extracted by ethyl acetate $(2 \times 10 \mathrm{~mL})$. Concentrated organic layer gave a syrup that was dissolved in $\mathrm{MeOH}(10 \mathrm{~mL})$, cooled to $0{ }^{\circ} \mathrm{C}$, and $\mathrm{NaBH}_{4}(0.101 \mathrm{~g}, 2.68 \mathrm{mmol})$ was added portionwise over a period of $20 \mathrm{~min}$. The reaction was maintained at $0{ }^{\circ} \mathrm{C}$ for another $30 \mathrm{~min}$ and then quenched by saturated aq $\mathrm{NH}_{4} \mathrm{Cl}$ and extracted by EtOAc $(2 \times 10 \mathrm{~mL})$. The EtOAc layer was concentrated and purified by column chromatography EtOAc/ PE (1:1) as mobile phase. A white solid 10 was observed (0.556 $\mathrm{mg}, 88 \%$ over two steps). $R_{f}=0.26$ in ethyl EtOAc; $\mathrm{mp}=122-$ $124{ }^{\circ} \mathrm{C}[\alpha]_{\mathrm{D}}{ }^{22}=+44.3\left(\mathrm{c} 0.101\right.$ methanol); IR $\left(\mathrm{KBr}, \nu, \mathrm{cm}^{-1}\right)$; 3232, 3130, 2949, 1545, 1448, 1379, 1242, 1168, 1101, 991, 871, 759; ${ }^{1} \mathrm{H}$ NMR $\left(500 \mathrm{MHz}, \mathrm{CDCl}_{3}\right) \delta 7.58(\mathrm{~s}, 1 \mathrm{H}), 6.36(\mathrm{~d}$, $J=3.6 \mathrm{~Hz}, 1 \mathrm{H}), 5.09(\mathrm{~d}, J=15.2 \mathrm{~Hz}, 1 \mathrm{H}), 4.87(\mathrm{~d}, J=15.2 \mathrm{~Hz}$, $1 \mathrm{H}), 4.84(\mathrm{~d}, J=3.6 \mathrm{~Hz}, 1 \mathrm{H}), 4.53(\mathrm{t}, J=5.4 \mathrm{~Hz}, 1 \mathrm{H}), 4.38(\mathrm{~d}$, $J=12.7 \mathrm{~Hz}, 1 \mathrm{H}), 4.14(\mathrm{~d}, J=12.7 \mathrm{~Hz}, 1 \mathrm{H}), 3.38-3.30(\mathrm{~m}$, $2 \mathrm{H}), 1.62(\mathrm{~s}, 4 \mathrm{H}), 1.38(\mathrm{~s}, 3 \mathrm{H}) ;{ }^{13} \mathrm{C} \mathrm{NMR}\left(125 \mathrm{MHz} \mathrm{CDCl}_{3}\right)$ $\delta 130.6,128.3,113.5,105.7,85.3,83.4,68.4,66.9,62.7,60.3$, 26.8, 26.4; HRMS calculated for $\mathrm{C}_{12} \mathrm{H}_{17} \mathrm{~N}_{3} \mathrm{O}_{5} \mathrm{Na}[\mathrm{M}+\mathrm{Na}]^{+}$ 306.1068, Found: 306.1074 . 
Synthesis of 11. Compound 10 (20.500 g, $1.77 \mathrm{mmol})$ was dissolved in dry dichloromethane $(10 \mathrm{~mL})$ and cooled to $0{ }^{\circ} \mathrm{C}$, to which dry pyridine $(0.426 \mathrm{~mL}, 5.30 \mathrm{mmol})$ was added dropwise followed by addition of $\mathrm{TsCl}(0.403 \mathrm{~g}, 2.12 \mathrm{mmol})$ pinchwise over $15 \mathrm{~min}$. The reaction was maintained at $0{ }^{\circ} \mathrm{C}$ for $30 \mathrm{~min}$ and then at RT for $3 \mathrm{~h}$. The reaction was quenched by $1 \mathrm{M}$ aq $\mathrm{HCl}$ solution and extracted using dichloromethane $(2 \times 10 \mathrm{~mL})$. The organic layer was concentrated, and the thick residue obtained was purified by column chromatography as mobile phase. A white solid 11 was observed (0.733 g, 95\%). $R_{f}$ $=0.50$ in EtOAc $/ \mathrm{PE}(2: 3) ; \mathrm{mp}=165-167^{\circ} \mathrm{C} ;[\alpha]_{\mathrm{D}}^{22}=+14.12$ (c 0.103 methanol); IR (KBr, $\left.\nu, \mathrm{cm}^{-1}\right)$; 3373, 2991, 2924, 1595, 1492, 1440, 1373, 1178, 1097, 981, 868, 763, 665, 555; ${ }^{1} \mathrm{H}$ NMR (500 MHz, $\left.\mathrm{CDCl}_{3}\right) \delta 7.66(\mathrm{~d}, J=8.3 \mathrm{~Hz}, 2 \mathrm{H}), 7.53(\mathrm{~s}$, $1 \mathrm{H}), 7.31(\mathrm{~d}, J=8.3 \mathrm{~Hz}, 2 \mathrm{H}), 6.25(\mathrm{~d}, J=3.5 \mathrm{~Hz}, 1 \mathrm{H}), 4.96(\mathrm{~d}$, $J=15.1 \mathrm{~Hz}, 1 \mathrm{H}), 4.87(\mathrm{~d}, J=15.1 \mathrm{~Hz}, 1 \mathrm{H}), 4.66(\mathrm{~d}, J=3.5 \mathrm{~Hz}$, $1 \mathrm{H}), 4.56(\mathrm{t}, J=5.5 \mathrm{~Hz}, 1 \mathrm{H}), 4.24\left(\mathrm{AB}_{q}, J=12.7 \mathrm{~Hz}, 1 \mathrm{H}\right), 4.00$ (dd, $J=10.8,5.5 \mathrm{~Hz}, 1 \mathrm{H}), 3.69$ (dd, $J=10.8,5.5 \mathrm{~Hz}, 1 \mathrm{H}), 2.44$ $(\mathrm{s}, 3 \mathrm{H}), 1.56(\mathrm{~s}, 3 \mathrm{H}), 1.34(\mathrm{~s}, 3 \mathrm{H}) ;{ }^{13} \mathrm{C}$ NMR $(125 \mathrm{MHz}$, $\left.\mathrm{CDCl}_{3}\right) \delta 145.3,132.2,131.2,130.0(2 \mathrm{C}), 128.5,128.0$ (2C), 113.8, 106.1, 85.0, 79.9, 68.7, 67.0, 66.2, 62.6, 27.0, 26.5, 21.7; HRMS calculated for $\mathrm{C}_{19} \mathrm{H}_{24} \mathrm{~N}_{3} \mathrm{O}_{7} \mathrm{~S}[\mathrm{M}+\mathrm{H}]^{+}$438.1335, Found: 438.1338.

Synthesis of 12. To a mixture of $11(0.600 \mathrm{~g}, 1.37 \mathrm{mmol})$, $\mathrm{NaN}_{3}(0.107 \mathrm{~g}, 1.65 \mathrm{mmol})$, and TBAI (0.051 g, 10\% mol) dry DMF $(10 \mathrm{~mL})$ was added under $\mathrm{N}_{2}$ environment and heated at $95{ }^{\circ} \mathrm{C}$ for $6 \mathrm{~h}$. The mixture was concentrated directly on a rotary evaporator, added with water $(5 \mathrm{~mL})$, extracted by EtOAc $(2 \times 10 \mathrm{~mL})$, concentrated, and purified by EtOAc/PE (1:1) as mobile phase using column chromatography. A white solid 12 was observed $(0.363 \mathrm{~g}, 86 \%) . R_{f}=0.55$, EtOAc/PE $(1: 1) ; \mathrm{mp}=191-193{ }^{\circ} \mathrm{C} ; \mathrm{IR}[\alpha]_{\mathrm{D}}{ }^{22}=+70.5(c \quad 0.104$ methanol); IR (KBr, $\left.\nu, \mathrm{cm}^{-1}\right)$; 2991, 2941, 2094, 1654, 1546, 1448, 1379, 1230, 1166, 1107, 991, 854, 763, 665, 549; ${ }^{1} \mathrm{H}$ NMR $\left(500 \mathrm{MHz}, \mathrm{CDCl}_{3}\right) \delta 7.58(\mathrm{~s}, 1 \mathrm{H}), 6.37(\mathrm{~d}, J=3.6 \mathrm{~Hz}$, $1 \mathrm{H}), 5.03(\mathrm{~d}, J=15.2 \mathrm{~Hz}, 1 \mathrm{H}), 4.84(\mathrm{~d}, J=15.2 \mathrm{~Hz}, 1 \mathrm{H}), 4.78$ $(\mathrm{d}, J=3.6 \mathrm{~Hz}, 1 \mathrm{H}), 4.53(\mathrm{dd}, J=7.7,3.8 \mathrm{~Hz}, 1 \mathrm{H}), 4.31(\mathrm{~d}, J=$ $12.8 \mathrm{~Hz}, 1 \mathrm{H}), 4.15$ (d, $J=12.8 \mathrm{~Hz}, 1 \mathrm{H}), 3.25$ (dd, $J=13.0,3.8$ $\mathrm{Hz}, 1 \mathrm{H}), 2.84$ (dd, $J=13.0,7.7 \mathrm{~Hz}, 1 \mathrm{H}), 1.61(\mathrm{~s}, 3 \mathrm{H}), 1.37$ (s, $3 \mathrm{H}) ;{ }^{13} \mathrm{C} \mathrm{NMR}\left(125 \mathrm{MHz}, \mathrm{CDCl}_{3}\right) \delta 130.9,128.5,113.7$, 106.1, 85.2, 82.3, 68.6, 66.9, 62.7, 50.3, 27.1, 26.5; HRMS calculated for $\mathrm{C}_{12} \mathrm{H}_{16} \mathrm{~N}_{6} \mathrm{O}_{4} \mathrm{Na}[\mathrm{M}+\mathrm{Na}]^{+} 331.1130$, Found: 331.1138 .

Synthesis of $3 a$. Compound $\mathbf{1 2}$ (0.300 g, $0.591 \mathrm{mmol})$ was dissolved in $75 \%$ aq $\mathrm{TFA} / \mathrm{H}_{2} \mathrm{O}\left(5 \mathrm{~mL}\right.$, precooled to $\left.0{ }^{\circ} \mathrm{C}\right)$, stirred at RT for $3 \mathrm{~h}$, concentrated on a rotary evaporator under vaccum followed by EtOAc addition, and the organic layer was washed with $10 \%$ aq $\mathrm{NaHCO}_{3}$ solution. Finally, the organic layer was filtered through a 60-120 mesh silica bed with eluting EtOAc and concentrated to obtain a thick residue. The thick residue was directly dissolved in methanol $(5 \mathrm{~mL})$, hydrogenated using $10 \% \mathrm{Pd} / \mathrm{C}$ (catalytic), and stirred at 100 psi pressure for $30 \mathrm{~h}$. The reaction mass was filtered through celite, concentrated, and purified by $\mathrm{MeOH} / \mathrm{CHCl}_{3}$ (1:4) as mobile phase. A white solid 3a ( $0.189 \mathrm{~g}, 86 \%$ over two steps) was observed. $R_{f}=0.45 \mathrm{MeOH} / \mathrm{CHCl}_{3}(1: 4) ; \mathrm{mp}=229-231$ ${ }^{\circ} \mathrm{C}$ (dec.); IR (KBr, $\nu, \mathrm{cm}^{-1}$ ) 3311, 3117, 2960, 2893, 1688, 1599, 1450, 1247, 1111, 1066, 999, 858, 761, 596; ${ }^{1} \mathrm{H}$ NMR $\left(500 \mathrm{MHz}, \mathrm{D}_{2} \mathrm{O}\right) \delta 7.71(\mathrm{~s}, 1 \mathrm{H}), 4.93(\mathrm{~s}, 2 \mathrm{H}), 4.48(\mathrm{dd}, J=$ $10.8,4.8 \mathrm{~Hz}, 1 \mathrm{H}), 4.43$ (s, $2 \mathrm{H}), 3.29$ (dd, $J=13.4,4.8 \mathrm{~Hz}, 2 \mathrm{H})$, $2.84(\mathrm{dd}, J=13.4,10.8 \mathrm{~Hz}, 2 \mathrm{H}) ;{ }^{13} \mathrm{C} \mathrm{NMR}\left(125 \mathrm{MHz}, \mathrm{D}_{2} \mathrm{O}\right) \delta$ 135.1, 128.9, 70.9(2C), 65.6, 61.9, 61.5, 46.0(2C); HRMS calculated for $\mathrm{C}_{9} \mathrm{H}_{15} \mathrm{~N}_{4} \mathrm{O}_{3}[\mathrm{M}+\mathrm{H}]^{+}$227.1139, Found: 227.1145.

Synthesis of 13. Dry dichloromethane $(10 \mathrm{~mL})$ and 6 $(0.500 \mathrm{~g}, 1.60 \mathrm{mmol})$ were mixed together and cooled to $0{ }^{\circ} \mathrm{C}$, to which imidazole $(0.239 \mathrm{~g}, 3.51 \mathrm{mmol})$ and TBDMSCl $(0.264 \mathrm{~g}, 1.76 \mathrm{mmol})$ were added and the reaction was maintained at RT for $2 \mathrm{~h}$. The reaction was quenched by $1 \mathrm{M}$ aq $\mathrm{HCl}$ solution and extracted by dichloromethane $(4 \times 10$ $\mathrm{mL}$ ); organic layers were mixed and concentrated, followed by purification of the obtained thick syrup by column chromatography using EtOAc/PE (1:4) as mobile phase to obtain a colorless thick syrup $13(0.648 \mathrm{~g}, 95 \%) . R_{f}=0.60$, EtOAc; $[\alpha]_{\mathrm{D}}{ }^{22}=-21.2$ (c 0.101, methanol); IR $\left(\mathrm{KBr}, \nu, \mathrm{cm}^{-1}\right)$; 3462, $2929,1464,1379,1249,1165,1095,1006,837,777,669 ;{ }^{1} \mathrm{H}$ $\mathrm{NMR}\left(500 \mathrm{MHz}, \mathrm{CDCl}_{3}\right) \delta 7.56(\mathrm{~s}, 1 \mathrm{H}), 6.22(\mathrm{~d}, J=3.5 \mathrm{~Hz}$, $1 \mathrm{H}), 5.00(\mathrm{~d}, J=14.7 \mathrm{~Hz}, 16 \mathrm{H}), 4.85(\mathrm{~d}, J=14.7 \mathrm{~Hz}, 1 \mathrm{H}), 4.54$ $(\mathrm{d}, J=12.3 \mathrm{~Hz}, 1 \mathrm{H}), 4.51(\mathrm{~d}, J=3.5 \mathrm{~Hz}, 1 \mathrm{H}), 4.34(\mathrm{~d}, J=12.3$ $\mathrm{Hz}, 1 \mathrm{H}), 4.14$ (d, $J=9.0 \mathrm{~Hz}, 1 \mathrm{H}), 3.77$ (dd, $J=10.2,3.1 \mathrm{~Hz}$, $1 \mathrm{H}), 3.72(\mathrm{dd}, J=10.2,5.1 \mathrm{~Hz}, 1 \mathrm{H}), 3.51-3.44(\mathrm{~m}, 1 \mathrm{H}$, after $\mathrm{D}_{2} \mathrm{O}$ ex., it appears as ddd $\left.J=9.0,5.1,3.1 \mathrm{~Hz}\right), 2.68(\mathrm{~d}, J=4.8$ $\mathrm{Hz}, 1 \mathrm{H}$, ex. with $\left.\mathrm{D}_{2} \mathrm{O}\right), 1.58(\mathrm{~s}, 3 \mathrm{H}), 1.35(\mathrm{~s}, 3 \mathrm{H}), 0.88(\mathrm{~s}, 9 \mathrm{H})$, 0.07 (s, 3H), $0.06(\mathrm{~s}, 3 \mathrm{H}) ;{ }^{13} \mathrm{C}$ NMR (125 MHz, $\left.\mathrm{CDCl}_{3}\right) \delta$ 131.9, 128.4, 113.4, 105.9, 85.3, 79.7, 70.1, 68.9, 65.4, 64.3, 62.7, 27.1, 26.6, 25.9 (3C), 18.3, -5.40, -5.45; HRMS calculated for $\mathrm{C}_{19} \mathrm{H}_{33} \mathrm{~N}_{3} \mathrm{O}_{6} \mathrm{SiNa}[\mathrm{M}+\mathrm{Na}]^{+}$450.2021, Found: 450.2022 .

Synthesis of 14. Compound $13(0.600 \mathrm{~g}, 1.40 \mathrm{mmol})$ was dissolved in dry dichloromethane $(10 \mathrm{~mL})$ and cooled to $0{ }^{\circ} \mathrm{C}$, to which dry pyridine $(0.283 \mathrm{~mL}, 3.51 \mathrm{mmol})$ was added slowly, followed by addition of triflic anhydride $(0.259 \mathrm{~mL}, 1.54$ mmol, diluted in $2 \mathrm{~mL}$ DCM) dropwise over $10 \mathrm{~min}$ and catalytic DMAP. The reaction was maintained at $0{ }^{\circ} \mathrm{C}$ for $1 \mathrm{~h}$, quenched by $1 \mathrm{M}$ aq $\mathrm{HCl}$ solution, and extracted twice with 5 $\mathrm{mL}$ of dichloromethane each time and concentrated. A thick syrup $(0.810 \mathrm{~g})$ was obtained, to which, without purification, $\mathrm{NaN}_{3}$ (0.129 g, $2.00 \mathrm{mmol}$, considering 95\% yield of OTf intermediate) and dry DMF $(5 \mathrm{~mL})$ were added. The reaction mass was heated to $65{ }^{\circ} \mathrm{C}$ for $1 \mathrm{~h}$, concentrated directly on a rotary evaporator, water $(5 \mathrm{~mL})$ was added, extracted with ethyl acetate $(2 \times 5 \mathrm{~mL})$, and evaporated. The obtained thick syrup was purified by column chromatography using EtOAc/PE (1:4) as mobile phase, and an off-white solid $14(0.584 \mathrm{~g}, 92 \%$ over two steps) was obtained. $R_{f}=0.37$ in EtOAc/PE (1:1); $\mathrm{mp}=$ $119-121{ }^{\circ} \mathrm{C}$; $[\alpha]_{\mathrm{D}}{ }^{22}=+50.5$ (c 0.103 methanol); IR (KBr, $\nu$, $\left.\mathrm{cm}^{-1}\right)$; 2987, 2933, 2858, 2112, 1643, 1464, 1379, 1249, 1170, 1095, 1037, 837, 775; ${ }^{1} \mathrm{H}$ NMR $\left(500 \mathrm{MHz}, \mathrm{CDCl}_{3}\right) \delta 7.60(\mathrm{~s}$, $1 \mathrm{H}), 6.43(\mathrm{~d}, J=3.6 \mathrm{~Hz}, 1 \mathrm{H}), 5.14(\mathrm{~d}, J=15.2 \mathrm{~Hz}, 1 \mathrm{H}), 4.88$ $(\mathrm{d}, J=15.2 \mathrm{~Hz}, 1 \mathrm{H}), 4.85(\mathrm{~d}, J=3.6 \mathrm{~Hz}, 1 \mathrm{H}), 4.57(\mathrm{~d}, J=2.0$ $\mathrm{Hz}, 1 \mathrm{H}), 4.35(\mathrm{~d}, J=12.7 \mathrm{~Hz}, 1 \mathrm{H}), 4.11(\mathrm{~d}, J=12.7 \mathrm{~Hz}, 1 \mathrm{H})$, $3.83(\mathrm{dd}, J=10.1,6.7 \mathrm{~Hz}, 1 \mathrm{H}), 3.77(\mathrm{dd}, J=10.1,6.7 \mathrm{~Hz}, 1 \mathrm{H})$, 3.55 (td, $J=6.7,2.0 \mathrm{~Hz}, 2 \mathrm{H}), 1.60(\mathrm{~s}, 3 \mathrm{H}), 1.38$ (s, 3H), 0.91 $(\mathrm{s}, 12 \mathrm{H}), 0.09(\mathrm{~s}, 3 \mathrm{H}), 0.08(\mathrm{~s}, 3 \mathrm{H}) ;{ }^{13} \mathrm{C}$ NMR $(125 \mathrm{MHz}$, $\left.\mathrm{CDCl}_{3}\right) \delta 130.3,128.4,113.3,105.6,85.0,80.5,67.7,67.1,63.2$, 62.5, 60.6, 26.8, 26.3, 25.8 (3C), 18.1, -5.51, -5.55; HRMS calculated for $\mathrm{C}_{19} \mathrm{H}_{33} \mathrm{~N}_{6} \mathrm{O}_{5} \mathrm{Si}[\mathrm{M}+\mathrm{H}]^{+}$453.2276, Found: 453.2286.

Synthesis of $4 a$. TFA ( $75 \%$ aq, $5 \mathrm{~mL}$, precooled to $0{ }^{\circ} \mathrm{C}$ ) was added to compound $14(0.500 \mathrm{mg}, 1.10 \mathrm{mmol})$, stirred at 0 ${ }^{\circ} \mathrm{C}$ for $3 \mathrm{~h}$, and concentrated under vacuum and saturated aq $\mathrm{NaHCO}_{3}(5 \mathrm{~mL})$, followed by EtOAC $(5 \mathrm{~mL})$ addition. The reaction was extracted twice with EtOAc $(2 \times 5 \mathrm{~mL})$ and the separated organic layer was filtered through a 60-120 mesh silica bed with eluting ethyl acetate and concentrated. A thick 
residue was obtained, which was directly dissolved in distilled $\mathrm{MeOH}(10 \mathrm{~mL})$, hydrogenated using 10\% Pd/C (cat.), stirred at $120 \mathrm{psi}$ pressure for $24 \mathrm{~h}$, filtered through celite, concentrated, and purified by $\mathrm{MeOH} / \mathrm{CHCl}_{3}(2: 3)$ as mobile phase. Compound $4 \mathrm{a}$ was obtained as a white solid $(0.220 \mathrm{~g}$, $78 \%$ over two steps). $R_{f}=0.35, \mathrm{MeOH} / \mathrm{CHCl}_{3}(2: 3) ; \mathrm{mp}=$ $114-116^{\circ} \mathrm{C}$; $[\alpha]_{\mathrm{D}}^{22}=-27.5$ (c 0.102, methanol); IR (KBr, $\nu$, $\left.\mathrm{cm}^{-1}\right)$; 3308, 2928, 1674, 1450, 1093, 939, 758; ${ }^{1} \mathrm{H}$ NMR (500 $\left.\mathrm{MHz}, \mathrm{D}_{2} \mathrm{O}\right) \delta 7.65(\mathrm{~s}, 1 \mathrm{H}), 5.02\left(\mathrm{AB}_{\mathrm{q}}, J=15.5 \mathrm{~Hz}, 2 \mathrm{H}\right), 4.32$ $\left(\mathrm{AB}_{\mathrm{q}} J=12.5 \mathrm{~Hz}, 2 \mathrm{H}\right), 4.11(\mathrm{~d}, J=2.6 \mathrm{~Hz}, 1 \mathrm{H}), 4.05(\mathrm{t}, J=3.3$ $\mathrm{Hz}, 1 \mathrm{H}), 3.71(\mathrm{dd}, J=11.0,6.5 \mathrm{~Hz}, 1 \mathrm{H}), 3.68(\mathrm{dd}, J=11.0,6.5$ $\mathrm{Hz}, 1 \mathrm{H}), 3.65-3.62(\mathrm{~m}, 1 \mathrm{H}), 3.60(\mathrm{dd}, J=14.4,3.3 \mathrm{~Hz}, 1 \mathrm{H})$, $3.07(\mathrm{dd}, J=14.4,3.3 \mathrm{~Hz}, 1 \mathrm{H}) ;{ }^{13} \mathrm{C}$ NMR $\left(125 \mathrm{MHz}, \mathrm{D}_{2} \mathrm{O}\right) \delta$ 133.0, 128.4, 68.2, 68.1, 66.6, 63.3, 62.1, 60.4, 56.0, 46.5; HRMS calculated for $\mathrm{C}_{10} \mathrm{H}_{17} \mathrm{~N}_{4} \mathrm{O}_{4}[\mathrm{M}+\mathrm{H}]^{+}$257.1249, Found: 257.1255

General Method for N-Alkylation. Iminosugar 3a/4a (1.0 equiv) was dissolved in dry DMF $(0.5 \mathrm{~mL})$, followed by addition of $\mathrm{K}_{2} \mathrm{CO}_{3}$ (2.2 equiv) and alkyl halide (1.1 equiv). The reaction mass was heated under $\mathrm{N}_{2}$ atmosphere and concentrated on a rotary evaporator under high vaccum, followed by column purification using $\mathrm{CHCl}_{3}$ and $\mathrm{MeOH}$ system as a mobile phase on silica gel 100-200 mesh size.

Synthesis of $3 b$. The reaction of $3 a(0.020 \mathrm{~g}, 88.40 \mu \mathrm{mol})$, $\mathrm{K}_{2} \mathrm{CO}_{3}(0.027 \mathrm{~g}, 194.49 \mu \mathrm{mol})$, and bromoethane $(0.007 \mathrm{~mL}$, $97.25 \mu \mathrm{mol})$ in DMF was maintained at $80{ }^{\circ} \mathrm{C}$ for $1 \mathrm{~h}$. Usual workup and purification by column chromatography using $\mathrm{CHCl}_{3} / \mathrm{MeOH}$ (1:9) as mobile phase gave $3 \mathbf{b}(0.021 \mathrm{~g}, 95 \%)$ as a white solid. $R_{f}=0.52, \mathrm{CHCl}_{3} / \mathrm{MeOH}(1: 4) ; \mathrm{mp}=147-$ $149{ }^{\circ} \mathrm{C}$; ${ }^{1} \mathrm{H}$ NMR $\left(400 \mathrm{MHz}, \mathrm{CD}_{3} \mathrm{OD}\right) \delta 7.47(\mathrm{~s}, 1 \mathrm{H}), 4.72(\mathrm{~s}$, $2 \mathrm{H}), 4.44(\mathrm{dd}, J=11.2,4.9 \mathrm{~Hz}, 2 \mathrm{H}), 4.25(\mathrm{~s}, 2 \mathrm{H}), 2.91$ (dd, $J=$ $11.2,4.9 \mathrm{~Hz}, 2 \mathrm{H}), 2.47(\mathrm{q}, J=7.2 \mathrm{~Hz}, 2 \mathrm{H}), 2.09(\mathrm{t}, J=11.2 \mathrm{~Hz}$, $2 \mathrm{H}), 1.04(\mathrm{t}, J=7.2 \mathrm{~Hz}, 3 \mathrm{H}) ;{ }^{13} \mathrm{C} \mathrm{NMR}\left(100 \mathrm{MHz}, \mathrm{CD}_{3} \mathrm{OD}\right) \delta$ 135.0, 127.4, 71.0 (2C), 65.9, 61.3, 61.2, 55.1 (2C), 51.1, 10.7; HRMS (ESI) $m / z$ calculated for $\mathrm{C}_{11} \mathrm{H}_{19} \mathrm{~N}_{4} \mathrm{O}_{3}(\mathrm{M}+\mathrm{H})^{+}$ 255.1452, Found: 255.1451.

Synthesis of 3c. The reaction of $3 \mathrm{a}(0.020 \mathrm{~g}, 88.40 \mu \mathrm{mol})$, $\mathrm{K}_{2} \mathrm{CO}_{3}(0.027 \mathrm{~g}, 194.49 \mu \mathrm{mol})$, and $n$-bromobutane $(0.010 \mathrm{~mL}$, $97.25 \mu \mathrm{mol})$ in DMF was carried out at $80{ }^{\circ} \mathrm{C}$ for $1 \mathrm{~h}$. Usual workup and purification by column chromatography using $\mathrm{CHCl}_{3} / \mathrm{MeOH}(1: 9)$ as mobile phase gave $3 \mathrm{c}(0.024 \mathrm{~g}$, 98\%) as a white solid. $R_{f}=0.55, \mathrm{CHCl}_{3} / \mathrm{MeOH}(1: 4) ; \mathrm{mp}=156-$ $158{ }^{\circ} \mathrm{C}$; ${ }^{1} \mathrm{H}$ NMR $\left(400 \mathrm{MHz}, \mathrm{CD}_{3} \mathrm{OD}\right) \delta 7.47(\mathrm{~s}, 1 \mathrm{H}), 4.72(\mathrm{~s}$, $2 \mathrm{H}), 4.43$ (dd, $J=11.2,4.9 \mathrm{~Hz}, 2 \mathrm{H}), 4.25(\mathrm{~s}, 2 \mathrm{H}), 2.90$ (dd, $J=$ $11.2,4.9 \mathrm{~Hz}, 2 \mathrm{H}), 2.39$ (q, $J=7.2 \mathrm{~Hz}, 2 \mathrm{H}), 2.09(\mathrm{t}, J=11.2 \mathrm{~Hz}$, $2 \mathrm{H}), 1.49-1.37(\mathrm{~m}, 2 \mathrm{H}), 1.28$ (sextate, $J=7.2 \mathrm{~Hz}, 2 \mathrm{H}), 0.87(\mathrm{t}$, $J=7.2 \mathrm{~Hz}, 3 \mathrm{H}) ;{ }^{13} \mathrm{C} \mathrm{NMR}\left(100 \mathrm{MHz}, \mathrm{CD}_{3} \mathrm{OD}\right) \delta 135.0,127.3$, 71.0 (2C), 65.9, 61.3, 61.2, 57.1, 55.6 (2C), 28.6, 20.2, 12.9; HRMS (ESI) $m / z$ calculated for $\mathrm{C}_{13} \mathrm{H}_{23} \mathrm{~N}_{4} \mathrm{O}_{3}(\mathrm{M}+\mathrm{H})^{+}$: 283.1765, Found: 283.1769.

Synthesis of $3 d$. The reaction of $3 \mathrm{a}(0.020 \mathrm{~g}, 88.40 \mu \mathrm{mol})$, $\mathrm{K}_{2} \mathrm{CO}_{3}(0.027 \mathrm{~g}, 194.49 \mu \mathrm{mol})$, and $n$-bromohexane $(0.014 \mathrm{~mL}$, $97.25 \mu \mathrm{mol})$ in DMF was carried out at $80{ }^{\circ} \mathrm{C}$ for $1 \mathrm{~h}$. Usual workup and purification by column chromatography using $\mathrm{CHCl}_{3} / \mathrm{MeOH}$ (1:9) as mobile phase gave 3d (0.024 g, 89\%) as a white solid. $R_{f}=0.56, \mathrm{CHCl}_{3} / \mathrm{MeOH}(1: 4) ; \mathrm{mp}=153-$ $155{ }^{\circ} \mathrm{C}$; ${ }^{1} \mathrm{H}$ NMR $\left(400 \mathrm{MHz}, \mathrm{CD}_{3} \mathrm{OD}\right) \delta 7.47(\mathrm{~s}, 1 \mathrm{H}), 4.72(\mathrm{~s}$, $2 \mathrm{H}), 4.43(\mathrm{dd}, J=11.2,4.9 \mathrm{~Hz}, 2 \mathrm{H}), 4.25(\mathrm{~s}, 2 \mathrm{H}), 2.90$ (dd, $J=$ $11.2,4.9 \mathrm{~Hz}, 2 \mathrm{H}), 2.38(\mathrm{q}, J=7.2 \mathrm{~Hz}, 2 \mathrm{H}), 2.09(\mathrm{t}, J=11.2 \mathrm{~Hz}$, $2 \mathrm{H}), 1.49-1.37(\mathrm{~m}, 2 \mathrm{H}), 1.30-1.21(\mathrm{~m}, 6 \mathrm{H}), 0.82(\mathrm{t}, J=7.2$ $\mathrm{Hz}, 3 \mathrm{H}) ;{ }^{13} \mathrm{C}$ NMR (100 MHz, CD $\left.3 \mathrm{OD}\right) \delta 135.0,127.5,70.9$ (2C), 65.9, 61.3, 61.2, 57.4, 55.5 (2C), 31.5, 26.8, 26.3, 22.3,
13.0; HRMS (ESI) $m / z$ calculated for $\mathrm{C}_{15} \mathrm{H}_{27} \mathrm{~N}_{4} \mathrm{O}_{3}(\mathrm{M}+\mathrm{H})^{+}$: 311.2084, Found: 311.2078 .

Synthesis of $3 \boldsymbol{e}$. The reaction of $3 \mathrm{a}(0.020 \mathrm{~g}, 88.40 \mu \mathrm{mol})$, $\mathrm{K}_{2} \mathrm{CO}_{3}(0.027 \mathrm{~g}, 194.49 \mu \mathrm{mol})$, and $n$-bromooctane $(0.017 \mathrm{~mL}$, $97.25 \mu \mathrm{mol})$ in DMF was carried out at $80{ }^{\circ} \mathrm{C}$ for $1 \mathrm{~h}$. Usual workup and purification by column chromatography using $\mathrm{CHCl}_{3} / \mathrm{MeOH}(1: 9)$ as mobile phase gave $3 \mathrm{e}(0.028 \mathrm{~g}, 94 \%)$ as a white solid. $R_{f}=0.58, \mathrm{CHCl}_{3} / \mathrm{MeOH}(1: 4) ; \mathrm{mp}=141-$ $143{ }^{\circ} \mathrm{C}$; ${ }^{1} \mathrm{H}$ NMR (400 MHz, CD 3 OD) $\delta 7.48(\mathrm{~s}, 1 \mathrm{H}), 4.73(\mathrm{~s}$, $2 \mathrm{H}), 4.44$ (dd, $J=11.5,4.9 \mathrm{~Hz}, 2 \mathrm{H}), 4.26(\mathrm{~s}, 2 \mathrm{H}), 2.91$ (dd, $J=$ $11.5,4.9 \mathrm{~Hz}, 2 \mathrm{H}), 2.42-2.36(\mathrm{~m}, 2 \mathrm{H}), 2.10(\mathrm{t}, J=11.5 \mathrm{~Hz}$, $2 \mathrm{H}), 1.49-1.41(\mathrm{~m}, 2 \mathrm{H}), 1.30-1.18(\mathrm{~m}, 10 \mathrm{H}), 0.82(\mathrm{t}, J=7.0$ $\mathrm{Hz}, 3 \mathrm{H}) ;{ }^{13} \mathrm{C}$ NMR $\left(125 \mathrm{MHz}, \mathrm{D}_{2} \mathrm{O}\right) \delta 135.0,127.4,71.0$ (2C), 65.9, 61.3, 61.2, 57.4, 55.6 (2C), 31.6, 29.2, 29.0, 27.1, 26.4, 22.3, 13.0; HRMS (ESI) $m / z$ calculated for $\mathrm{C}_{17} \mathrm{H}_{31} \mathrm{~N}_{4} \mathrm{O}_{3}$ $(\mathrm{M}+\mathrm{H})^{+}$: 339.2391 , Found: 339.2390 .

Synthesis of $3 f$. The reaction of $3 \mathrm{a}(0.020 \mathrm{~g}, 88.40 \mu \mathrm{mol})$, $\mathrm{K}_{2} \mathrm{CO}_{3}(0.027 \mathrm{~g}, 194.49 \mu \mathrm{mol})$, and $n$-bromodecane $(0.020 \mathrm{~mL}$, $97.25 \mu \mathrm{mol})$ in DMF was carried out at $60{ }^{\circ} \mathrm{C}$ for $1 \mathrm{~h}$. Usual workup and purification by column chromatography using $\mathrm{CHCl}_{3} / \mathrm{MeOH}(1: 9)$ as mobile phase gave $3 \mathrm{f}(0.029 \mathrm{~g}, 92 \%)$ as a white solid. $R_{f}=0.60, \mathrm{CHCl}_{3} / \mathrm{MeOH}(1: 4) ; \mathrm{mp}=147-149$ ${ }^{\circ} \mathrm{C}$; ${ }^{1} \mathrm{H}$ NMR $\left(400 \mathrm{MHz}, \mathrm{CD}_{3} \mathrm{OD}\right) \delta 7.47$ (s, $\left.1 \mathrm{H}\right), 4.72(\mathrm{~s}$, $2 \mathrm{H}), 4.43$ (dd, $J=11.5,4.4 \mathrm{~Hz}, 2 \mathrm{H}), 4.25(\mathrm{~s}, 2 \mathrm{H}), 2.90$ (dd, $J=$ 11.5, $4.4 \mathrm{~Hz}, 2 \mathrm{H}$ ), 2.39 (App. triplet, $J=7.7 \mathrm{~Hz}, 2 \mathrm{H}), 2.09(\mathrm{t}, J$ $=11.5 \mathrm{~Hz}, 2 \mathrm{H}), 1.50-1.40(\mathrm{~m}, 2 \mathrm{H}), 1.31-1.12(\mathrm{~m}, 14 \mathrm{H}), 0.81$ $(\mathrm{t}, J=7.7 \mathrm{~Hz}, 3 \mathrm{H}) ;{ }^{13} \mathrm{C} \mathrm{NMR}\left(125 \mathrm{MHz}, \mathrm{D}_{2} \mathrm{O}\right) \delta 135.0,127.4$, 71.0 (2C), 66.0, 61.3, 61.2, 57.4, 55.6 (2C), 31.7, 29.33, 29.30, 29.2, 29.1, 27.1, 26.4, 22.3, 13.0; HRMS (ESI) $\mathrm{m} / z$ calculated for $\mathrm{C}_{19} \mathrm{H}_{35} \mathrm{~N}_{4} \mathrm{O}_{3}(\mathrm{M}+\mathrm{H})^{+}$: 367.2704, Found: 367.2703.

Synthesis of $3 \mathrm{~g}$. The reaction of $3 \mathrm{a}(0.020 \mathrm{~g}, 88.40 \mu \mathrm{mol})$, $\mathrm{K}_{2} \mathrm{CO}_{3}(0.027 \mathrm{~g}, 194.49 \mu \mathrm{mol})$, and $n$-bromododecane $(0.023$ $\mathrm{mL}, 97.25 \mu \mathrm{mol})$ in DMF was carried out at $60{ }^{\circ} \mathrm{C}$ for $1 \mathrm{~h}$. Usual workup and purification by column chromatography using $\mathrm{CHCl}_{3} / \mathrm{MeOH}(1: 9)$ as mobile phase gave $3 \mathrm{~g}$ (0.031 g, $90 \%)$ as a white solid. $R_{f}=0.66, \mathrm{CHCl}_{3} / \mathrm{MeOH}(1: 4) ; \mathrm{mp}=$ $214-216{ }^{\circ} \mathrm{C}$; ${ }^{1} \mathrm{H}$ NMR (400 MHz, $\left.\mathrm{CD}_{3} \mathrm{OD}\right) \delta 7.47(\mathrm{~s}, 1 \mathrm{H})$, $4.72(\mathrm{~s}, 2 \mathrm{H}), 4.43$ (dd, $J=11.2,4.8 \mathrm{~Hz}, 2 \mathrm{H}), 4.25(\mathrm{~s}, 2 \mathrm{H}), 2.90$ (dd, $J=11.2,4.8 \mathrm{~Hz}, 2 \mathrm{H}$ ), 2.38 (App. $\mathrm{t}, J=7.7 \mathrm{~Hz}, 2 \mathrm{H}$ ), 2.09 $(\mathrm{t}, J=11.2 \mathrm{~Hz}, 2 \mathrm{H}), 1.50-1.40(\mathrm{~m}, 2 \mathrm{H}), 1.30-1.13(\mathrm{~m}, 18 \mathrm{H})$, $0.80(\mathrm{t}, J=7.7 \mathrm{~Hz}, 3 \mathrm{H}) ;{ }^{13} \mathrm{C} \mathrm{NMR}\left(100 \mathrm{MHz}, \mathrm{CD}_{3} \mathrm{OD}\right) \delta$ 135.0, 127.3, 71.0 (2C), 66.0, 61.3, 61.2, 57.4, 55.6 (2C), 31.7, 29.4, 29.32, 29.30, 29.2, 29.1, 27.1, 26.4, 22.3, 13.0; HRMS (ESI) $m / z$ calculated for $\mathrm{C}_{21} \mathrm{H}_{39} \mathrm{~N}_{4} \mathrm{O}_{3}(\mathrm{M}+\mathrm{H})^{+}$: 395.3017, Found: 395.3017.

Synthesis of $\mathbf{4 b}$. The reaction of $4 \mathrm{a}(0.020 \mathrm{~g}, 78.05 \mu \mathrm{mol})$, $\mathrm{K}_{2} \mathrm{CO}_{3}(0.024 \mathrm{~g}, 171.70 \mu \mathrm{mol})$, and bromoethane $(0.006 \mathrm{~mL}$, $85.85 \mu \mathrm{mol})$ in DMF was carried out at $60{ }^{\circ} \mathrm{C}$ for $2 \mathrm{~h}$. Usual workup and purification by column chromatography using $\mathrm{CHCl}_{3} / \mathrm{MeOH}(2: 3)$ as mobile phase gave $4 \mathrm{~b}(0.020 \mathrm{~g}, 93 \%)$ as a thick syrup. $R_{f}=0.46, \mathrm{CHCl}_{3} / \mathrm{MeOH}(2: 3) ;[\alpha]_{\mathrm{D}}^{22}=+0.5$ (c 0.15, methanol); ${ }^{1} \mathrm{H}$ NMR (400 MHz, $\left.\mathrm{CD}_{3} \mathrm{OD}\right) \delta 7.45$ (s, $1 \mathrm{H}), 4.85(\mathrm{~d}, J=15.0 \mathrm{~Hz}, 1 \mathrm{H}), 4.74(\mathrm{~d}, J=15.0 \mathrm{~Hz}, 1 \mathrm{H}), 4.24$ $(\mathrm{d}, J=4.7 \mathrm{~Hz}, 1 \mathrm{H}), 4.16\left(\mathrm{AB}_{\mathrm{q}}, J=12.2 \mathrm{~Hz}, 1 \mathrm{H}\right), 4.10(\mathrm{dd}, J=$ 8.0, $3.6 \mathrm{~Hz}, 1 \mathrm{H}), 3.71(\mathrm{dd}, J=11.0,6.0 \mathrm{~Hz}, 1 \mathrm{H}), 3.67(\mathrm{dd}, J=$ $11.0,4.7 \mathrm{~Hz}, 1 \mathrm{H}$ ), 3.30 (App. q, $J=4.7 \mathrm{~Hz}, 1 \mathrm{H}), 3.21$ (dd, $J=$ $12.8,3.6 \mathrm{~Hz}, 1 \mathrm{H}), 2.85-2.71(\mathrm{~m}, 3 \mathrm{H}), 1.06(\mathrm{t}, J=7.1 \mathrm{~Hz}, 3 \mathrm{H})$; ${ }^{13} \mathrm{C}$ NMR $\left(100 \mathrm{MHz}, \mathrm{CD}_{3} \mathrm{OD}\right) \delta 133.6,127.3,78.1,70.5,69.8$, 65.5, 64.9, 62.0, 61.7, 58.3, 51.6, 10.2; HRMS (ESI) $m / z$ calculated for $\mathrm{C}_{12} \mathrm{H}_{21} \mathrm{~N}_{4} \mathrm{O}_{4}(\mathrm{M}+\mathrm{H})^{+}$: 285.1557, Found: 285.1557.

Synthesis of $4 c$. The reaction of $4 \mathrm{a}(0.020 \mathrm{~g}, 78.05 \mu \mathrm{mol})$, $\mathrm{K}_{2} \mathrm{CO}_{3}(0.024 \mathrm{~g}, 171.70 \mu \mathrm{mol}), n$-bromobutane $(0.010 \mathrm{~mL}$, 
$85.85 \mu \mathrm{mol}$ ) in DMF at $60{ }^{\circ} \mathrm{C}$ for $2 \mathrm{~h}$. Usual workup and purification by column chromatography using $\mathrm{CHCl}_{3} / \mathrm{MeOH}$ $(2: 3)$ as mobile phase gave $4 \mathrm{c}(0.021 \mathrm{~g}, 89 \%)$ as a thick syrup. $R_{f}=0.50, \mathrm{CHCl}_{3} / \mathrm{MeOH}(2: 3) ;[\alpha]_{\mathrm{D}}{ }^{22}=+6.4$ (c 0.13, methanol); ${ }^{1} \mathrm{H}$ NMR (400 MHz, $\left.\mathrm{CD}_{3} \mathrm{OD}\right) \delta 7.45(\mathrm{~s}, 1 \mathrm{H}), 4.84$ $(\mathrm{d}, J=15.0 \mathrm{~Hz}, 1 \mathrm{H}), 4.72(\mathrm{~d}, J=15.0 \mathrm{~Hz}, 1 \mathrm{H}), 4.28(\mathrm{~d}, J=4.3$ $\mathrm{Hz}, 1 \mathrm{H}$ ), 4.18 (d, $J=12.2 \mathrm{~Hz}, 1 \mathrm{H}), 4.13$ (dd, $J=8.1,3.9 \mathrm{~Hz}$, $1 \mathrm{H}), 4.11(\mathrm{~d}, J=12.2 \mathrm{~Hz}, 1 \mathrm{H}), 3.70(\mathrm{dd}, J=12.0,4.3 \mathrm{~Hz}, 1 \mathrm{H})$, $3.68(\mathrm{dd}, J=12.0,4.3 \mathrm{~Hz}, 1 \mathrm{H}), 3.25(\mathrm{dd}, J=12.9,3.9 \mathrm{~Hz}, 1 \mathrm{H})$, $3.13(\mathrm{dd}, J=6.9,3.9 \mathrm{~Hz}, 1 \mathrm{H}) 2.76(\mathrm{dd}, J=12.9,7.3 \mathrm{~Hz}, 1 \mathrm{H})(\mathrm{s}$, $3 \mathrm{H}), 2.74-2.61(\mathrm{~m}, 2 \mathrm{H}), 1.55-1.41(\mathrm{~m}, 2 \mathrm{H}), 1.28$ (sextate, $J=$ $7.4 \mathrm{~Hz}), 0.87(\mathrm{t}, J=7.3 \mathrm{~Hz}, 3 \mathrm{H}) ;{ }^{13} \mathrm{C} \mathrm{NMR}\left(125 \mathrm{MHz}, \mathrm{CDCl}_{3}\right)$ $\delta 136.1,129.5,72.9,72.2,67.5,67.4,65.0,63.9,60.4,55.6,54.0$, 30.6, 22.4, 15.2; HRMS (ESI) $m / z$ calculated for $\mathrm{C}_{14} \mathrm{H}_{25} \mathrm{~N}_{4} \mathrm{O}_{4}$ $(\mathrm{M}+\mathrm{H})^{+}:$313.1870, Found: 313.1870 .

Synthesis of $4 d$. The reaction of $4 a(0.020 \mathrm{~g}, 78.05 \mu \mathrm{mol})$, $\mathrm{K}_{2} \mathrm{CO}_{3}(0.024 \mathrm{~g}, 171.70 \mu \mathrm{mol})$, and $n$-bromohexane $(0.012 \mathrm{~mL}$, $85.85 \mu \mathrm{mol}$ ) in DMF was carried out at $60{ }^{\circ} \mathrm{C}$ for $2 \mathrm{~h}$. Usual workup and purification by column chromatography using $\mathrm{CHCl}_{3} / \mathrm{MeOH}(2: 3)$ as mobile phase gave $4 \mathrm{~d}(0.024 \mathrm{~g}, 90 \%)$ as a thick syrup. $R_{\mathrm{f}}=0.52, \mathrm{CHCl}_{3} / \mathrm{MeOH}(2: 3) ;[\alpha]_{\mathrm{D}}{ }^{22}=+1.7$ (c 0.15, methanol); ${ }^{1} \mathrm{H} \mathrm{NMR}\left(400 \mathrm{MHz}, \mathrm{CD}_{3} \mathrm{OD}\right) \delta 7.45$ (s, $1 \mathrm{H}), 4.84(\mathrm{~d}, J=15.0 \mathrm{~Hz}, 1 \mathrm{H}), 4.72(\mathrm{~d}, J=15.0 \mathrm{~Hz}, 1 \mathrm{H}), 4.28$ $(\mathrm{d}, J=4.3 \mathrm{~Hz}, 1 \mathrm{H}), 4.18(\mathrm{~d}, J=12.1 \mathrm{~Hz}, 1 \mathrm{H}), 4.12(\mathrm{dd}, J=7.9$, $3.7 \mathrm{~Hz}, 1 \mathrm{H}), 4.11(\mathrm{~d}, J=12.1 \mathrm{~Hz}, 1 \mathrm{H}), 3.69$ (dd, $J=11.2,4.3$ $\mathrm{Hz}, 1 \mathrm{H}$ ), 3.67 (dd, $J=11.2,4.3 \mathrm{~Hz}, 1 \mathrm{H}$ ), 3.25 (App. q, $J=4.3$ $\mathrm{Hz}, 1 \mathrm{H}), 3.13(\mathrm{dd}, J=12.9,3.7 \mathrm{~Hz}, 1 \mathrm{H}), 2.80-2.60(\mathrm{~m}, 3 \mathrm{H})$, $1.55-1.42(\mathrm{~m}, 2 \mathrm{H}), 1.32-1.20(\mathrm{~m}, 6 \mathrm{H}), 0.82(\mathrm{t}, J=6.7 \mathrm{~Hz}$, $3 \mathrm{H}) ;{ }^{13} \mathrm{C}$ NMR (100 MHz, $\left.\mathrm{CD}_{3} \mathrm{OD}\right) \delta 136.0,129.5,72.9,72.2$, 67.5, 67.4, 64.9, 63.9, 60.4, 55.9, 54.0, 33.8, 29.0, 28.3, 24.6, 15.3; HRMS (ESI) $m / z$ calculated for $\mathrm{C}_{16} \mathrm{H}_{29} \mathrm{~N}_{4} \mathrm{O}_{4}(\mathrm{M}+\mathrm{H})^{+}$: 341.2183, Found: 341.2193.

Synthesis of $4 \boldsymbol{e}$. The reaction of $4 \mathrm{a}(0.020 \mathrm{~g}, 78.05 \mu \mathrm{mol})$, $\mathrm{K}_{2} \mathrm{CO}_{3}(0.024 \mathrm{~g}, 171.70 \mu \mathrm{mol})$, and $n$-bromooctane $(0.015 \mathrm{~mL}$, $85.85 \mu \mathrm{mol})$ in DMF was carried out at $60{ }^{\circ} \mathrm{C}$ for $2 \mathrm{~h}$. Usual workup and purification by column chromatography using $\mathrm{CHCl}_{3} / \mathrm{MeOH}(2: 3)$ as mobile phase gave $4 \mathrm{e}(0.026 \mathrm{~g}$, 92\%) as a thick syrup. $R_{\mathrm{f}}=0.53, \mathrm{CHCl}_{3} / \mathrm{MeOH}(2: 3) ;[\alpha]_{\mathrm{D}}{ }^{22}=+7.5$ (c 0.14, methanol); ${ }^{1} \mathrm{H}$ NMR $\left(400 \mathrm{MHz}, \mathrm{CD}_{3} \mathrm{OD}\right) \delta 7.45$ (s, $1 \mathrm{H}), 4.84(\mathrm{~d}, J=15.0 \mathrm{~Hz}, 1 \mathrm{H}), 4.73(\mathrm{~d}, J=15.0 \mathrm{~Hz}, 1 \mathrm{H}), 4.28$ $(\mathrm{d}, J=4.9 \mathrm{~Hz}, 1 \mathrm{H}), 4.16(\mathrm{~d}, J=12.1 \mathrm{~Hz}, 1 \mathrm{H}), 4.13(\mathrm{dd}, J=8.1$, $3.9 \mathrm{~Hz}, 1 \mathrm{H}), 4.11(\mathrm{~d}, J=12.1 \mathrm{~Hz}, 1 \mathrm{H}), 3.68(\mathrm{dd}, J=11.3,6.2$ Hz, $1 \mathrm{H}$ ), 3.66 (dd, $J=11.3,4.9 \mathrm{~Hz}, 1 \mathrm{H}$ ), 3.25 (App. q, $J=4.9$ $\mathrm{Hz}, 1 \mathrm{H}), 3.13(\mathrm{dd}, J=12.9,3.9 \mathrm{~Hz}, 1 \mathrm{H}), 2.80-2.60(\mathrm{~m}, 3 \mathrm{H})$, $1.58-1.43(\mathrm{~m}, 2 \mathrm{H}), 1.32-1.15(\mathrm{~m}, 10 \mathrm{H}), 0.81(\mathrm{t}, J=6.8 \mathrm{~Hz}$, $3 \mathrm{H}) ;{ }^{13} \mathrm{C}$ NMR $\left(100 \mathrm{MHz}, \mathrm{CD}_{3} \mathrm{OD}\right) \delta 136.0,129.5,72.9,72.2$, $67.5,67.4,64.9,63.9,60.4,55.9,54.0,33.9,31.5,31.6,31.3$, 29.3, 28.3, 24.6, 15.3; HRMS (ESI) $\mathrm{m} / z$ calculated for $\mathrm{C}_{18} \mathrm{H}_{33} \mathrm{~N}_{4} \mathrm{O}_{4}(\mathrm{M}+\mathrm{H})^{+}:$369.2496, Found: 369.2502 .

Synthesis of $4 f$. The reaction of $4 \mathrm{a}(0.020 \mathrm{~g}, 78.05 \mu \mathrm{mol})$, $\mathrm{K}_{2} \mathrm{CO}_{3}(0.024 \mathrm{~g}, 171.70 \mu \mathrm{mol})$, and $n$-bromodecane $(0.018 \mathrm{~mL}$, $85.85 \mu \mathrm{mol})$ in DMF was carried out at $60{ }^{\circ} \mathrm{C}$ for $2 \mathrm{~h}$. Usual workup and purification by column chromatography using $\mathrm{CHCl}_{3} / \mathrm{MeOH}(2: 3)$ as mobile phase gave $4 \mathrm{f}(0.28 \mathrm{~g}, 90 \%)$ as a thick syrup. $R_{f}=0.55, \mathrm{CHCl}_{3} / \mathrm{MeOH}(2: 3) ;[\alpha]_{\mathrm{D}}{ }^{22}=+6.6(c$ 0.16, methanol); ${ }^{1} \mathrm{H}$ NMR $\left(400 \mathrm{MHz}, \mathrm{CD}_{3} \mathrm{OD}\right) \delta 7.45(\mathrm{~s}, 1 \mathrm{H})$, $4.84(\mathrm{~d}, J=15.0 \mathrm{~Hz}, 1 \mathrm{H}), 4.73(\mathrm{~d}, J=15.0 \mathrm{~Hz}, 1 \mathrm{H}), 4.28$ (d, $J$ $=4.9 \mathrm{~Hz}, 1 \mathrm{H}), 4.18(\mathrm{~d}, J=12.1 \mathrm{~Hz}, 1 \mathrm{H}), 4.13(\mathrm{dd}, J=8.5,3.9$ $\mathrm{Hz}, 1 \mathrm{H}), 4.11(\mathrm{~d}, J=12.1 \mathrm{~Hz}, 1 \mathrm{H}), 3.70(\mathrm{dd}, J=11.2,6.2 \mathrm{~Hz}$, $1 \mathrm{H}), 3.66(\mathrm{dd}, J=11.2,4.9 \mathrm{~Hz}, 1 \mathrm{H}), 3.25$ (App. q, $J=4.9 \mathrm{~Hz}$, $1 \mathrm{H}), 3.13(\mathrm{dd}, J=12.9,3.9 \mathrm{~Hz}, 1 \mathrm{H}), 2.74-2.61(\mathrm{~m}, 2 \mathrm{H}), 2.76$ $(\mathrm{dd}, J=12.9,8.5 \mathrm{~Hz}, 1 \mathrm{H}), 1.55-1.42(\mathrm{~m}, 2 \mathrm{H}), 1.30-1.12(\mathrm{~m}$, $14 \mathrm{H}), 0.80(\mathrm{t}, J=6.8 \mathrm{~Hz}, 3 \mathrm{H}) ;{ }^{13} \mathrm{C} \mathrm{NMR}\left(100 \mathrm{MHz}, \mathrm{CD}_{3} \mathrm{OD}\right)$ $\delta 136.0,129.5,72.9,72.2,67.5,67.4,64.9,63.9,60.4,55.9,54.0$, 33.9, 31.7, 31.6, 31.55, 31.3, 29.3, 24.6, 15.3; HRMS (ESI) $\mathrm{m} / \mathrm{z}$ calculated for $\mathrm{C}_{20} \mathrm{H}_{37} \mathrm{~N}_{4} \mathrm{O}_{4}(\mathrm{M}+\mathrm{H})^{+}:$397.2809, Found: 397.2820.

Synthesis of $\mathbf{4 g}$. The reaction of $4 \mathrm{a}(0.020 \mathrm{~g}, 78.05 \mu \mathrm{mol})$, $\mathrm{K}_{2} \mathrm{CO}_{3}(0.024 \mathrm{~g}, 171.70 \mu \mathrm{mol})$, and $n$-bromododecane $(0.021$ $\mathrm{mL}, 85.85 \mu \mathrm{mol})$ in DMF was carried out at $60{ }^{\circ} \mathrm{C}$ for $2 \mathrm{~h}$. Usual workup and purification by column chromatography using $\mathrm{CHCl}_{3} / \mathrm{MeOH}(2: 3)$ as mobile phase gave $4 \mathrm{~g}$ (0.029 g, $89 \%)$ as a thick syrup. $R_{f}=0.59, \mathrm{CHCl}_{3} / \mathrm{MeOH}(2: 3) ;[\alpha]_{\mathrm{D}}{ }^{22}=$ +18.8 (c 0.10, methanol); ${ }^{1} \mathrm{H}$ NMR (400 MHz, $\left.\mathrm{CD}_{3} \mathrm{OD}\right) \delta$ $7.45(\mathrm{~s}, 1 \mathrm{H}), 4.84(\mathrm{~d}, J=15.0 \mathrm{~Hz}, 1 \mathrm{H}), 4.73(\mathrm{~d}, J=15.0 \mathrm{~Hz}$, $1 \mathrm{H}), 4.29$ (d, $J=4.3 \mathrm{~Hz}, 1 \mathrm{H}), 4.18(\mathrm{~d}, J=12.1 \mathrm{~Hz}, 1 \mathrm{H}), 4.13$ (dd, $J=8.0,3.9 \mathrm{~Hz}, 1 \mathrm{H}), 4.11(\mathrm{~d}, J=12.1 \mathrm{~Hz}, 1 \mathrm{H}), 3.70$ (dd, $J$ $=11.2,5.2 \mathrm{~Hz}, 1 \mathrm{H}), 3.66(\mathrm{dd}, J=11.2,4.9 \mathrm{~Hz}, 1 \mathrm{H}), 3.25$ (App. q, $J=4.9 \mathrm{~Hz}, 1 \mathrm{H}), 3.13(\mathrm{dd}, J=12.9,3.9 \mathrm{~Hz}, 1 \mathrm{H}), 2.76(\mathrm{dd}, J=$ $12.9,8.0 \mathrm{~Hz}, 1 \mathrm{H}), 2.74-2.60(\mathrm{~m}, 2 \mathrm{H}), 1.55-1.45(\mathrm{~m}, 2 \mathrm{H})$, $1.30-1.13(\mathrm{~m}, 18 \mathrm{H}), 0.80(\mathrm{t}, J=6.8 \mathrm{~Hz}, 3 \mathrm{H}) ;{ }^{13} \mathrm{C} \mathrm{NMR}(100$ $\left.\mathrm{MHz}, \mathrm{CD}_{3} \mathrm{OD}\right) \delta 133.8,127.3,70.6,70.0,65.3,65.1,62.7,61.6$, 58.2, 53.6, 51.8, 31.7, 29.4, 29.35, 29.3, 29.1, 27.1, 26.0, 22.3, 13.0; HRMS (ESI) $m / z$ calculated for $\mathrm{C}_{22} \mathrm{H}_{41} \mathrm{~N}_{4} \mathrm{O}_{4}(\mathrm{M}+\mathrm{H})^{+}$: 425.3122, Found: 425.3135.

Conformational Analysis Protocol for DFT Method. To investigate conformational preferences of compounds $3 \mathbf{a}, 3 \mathbf{c}$, $4 a$, and $4 c$ and to corroborate our NMR experimental observations, we have performed quantum chemical calculations using the density functional theory (DFT) method. The initial geometries $\left({ }^{2} C_{5}\right.$ and ${ }^{5} C_{2}$ conformations) for compounds $3 \mathrm{a}$ and $3 \mathrm{c}$ and $\left({ }^{1} C_{4}\right.$ and ${ }^{4} C_{1}$ conformations) for compounds $4 a$ and $4 c$ have been generated using molecular modeling Spartan'14 software (wavefunction.in). Automated complete geometry optimizations were performed using the DFT method by employing B3LYP/6-31 $\mathrm{G}^{* *}$ basic set function on Spartan'14 software. Pictorial presentations of DFToptimized geometries of compounds have been made using Mercury 3.7 software.

Methodology Used for Biological Activities. Glycosidase Inhibitory Activity. Glycosidase inhibition assay for compounds $1,2,3 \mathbf{a}-\mathbf{g}$, and $\mathbf{4 a}-\mathbf{g}$ was carried out by mixing 0.1 $\mathrm{U} \mathrm{cm}{ }^{-3}$ each of $\alpha$-, $\beta$-glucosidase, $\alpha$-, $\beta$-galactosidase, and $\alpha$ mannosidase, and the samples were incubated for $1 \mathrm{~h}$ at $37^{\circ} \mathrm{C}$. Enzyme action for $\alpha / \beta$-galactosidase was initiated by addition of $10 \mathrm{mM} p$-nitrophenyl- $\alpha$ - $/ \beta$-D-galactopyranoside ( $p \mathrm{NPG})$ as a substrate in $200 \mathrm{mM}$ sodium acetate buffer. The reaction was incubated at $37^{\circ} \mathrm{C}$ for $10 \mathrm{~min}$ and stopped by adding $2 \mathrm{~cm}^{3}$ of $200 \mathrm{mM}$ borate buffer of $\mathrm{pH}$ 9.8. $\alpha$-Mannosidase activity was initiated by addition of $10 \mathrm{mM} p$-nitrophenyl- $\alpha$-D-mannopyranoside as a substrate in $100 \mathrm{mM}$ citrate buffer of $\mathrm{pH}$ 4.5. The reaction was incubated at $37{ }^{\circ} \mathrm{C}$ for $10 \mathrm{~min}$ and stopped by adding $2 \mathrm{~cm}^{3}$ of $200 \mathrm{mM}$ borate buffer of $\mathrm{pH} 9.8$. Initiation of $\alpha$-glucosidase activity was done by addition of $10 \mathrm{mM} p$ nitrophenyl- $\alpha$-D-glucopyranoside in $100 \mathrm{mM}$ phosphate buffer of $\mathrm{pH} 6.8$ and stopped by adding $2 \mathrm{~cm}^{3}$ of $0.1 \mathrm{M} \mathrm{Na}_{2} \mathrm{CO}_{3}$ after an incubation of $10 \mathrm{~min}$ at $37{ }^{\circ} \mathrm{C}$. Glycosidase activity was determined by measuring absorbance of the $p$-nitrophenol released from $p$ NPG at $420 \mathrm{~nm}$ using Molecular Devices Spectramax M5 mulitmode plate reader. One unit of glycosidase activity is defined as the amount of enzyme that hydrolyzed $1 \mathrm{mM}$ of $p$-nitrophenyl pyranoside per minute under assay condition.

Inhibition constant $\left(K_{\mathrm{i}}\right)$ values were determined by spectrophotometrically measuring the residual hydrolytic activities of the glycosidases in the presence of compounds. 
Each assay was performed in the appropriate buffer at the optimal $\mathrm{pH}$ for the enzymes. The reactions were initiated by addition of enzyme to a solution of the substrate in the absence or presence of various concentrations of inhibitor. Approximate values of $K_{\mathrm{i}}$ were determined using a fixed concentration of substrate (around the $K_{\mathrm{M}}$ value for the different glycosidases) and various concentrations of inhibitor. Full $K_{\mathrm{i}}$ determinations and enzyme inhibition mode were determined from the slope of Lineweaver-Burk plots and double reciprocal analysis.

Antifungal Activity. Minimal Inhibition Concentration (MIC) Assay. Fungal strains Candida albicans NCIM 3557 were procured from National Chemical Lab, Repository. Using the multipipette dispense, $100 \mu \mathrm{L}$ of LB medium was dispensed in all wells of microliter plate. The plate and lid were labeled, and $100 \mu \mathrm{L}$ of $2 \times$ antibiotic solutions was pipette into wells in column 1 . Using the multipipette set at $100 \mu \mathrm{L}$, the antibiotics were mixed into the wells of column 1 by sucking up and down six to seven times. A volume of $100 \mu \mathrm{L}$ from column 1 was withdrawn and added to column 2 . This made column 2 a twofold dilution of column 1, column 3 a twofold dilution of column 3, and so on. Similar procedure was repeated for the test compounds $\mathbf{1}, \mathbf{2}, \mathbf{3} \mathbf{a}-\mathbf{g}$, and $\mathbf{4 a}-\mathbf{g}$. The plates were incubated at $30{ }^{\circ} \mathrm{C}$ for $24 \mathrm{~h}$ and scanned with an ELISA plate reader. All experiments were run in triplicate, and standard deviations were determined.

Bright-Field Images. Candida albicans. SC5314 strain obtained from MTCC (National Chemical Lab, Pune) was inoculated in six-well sterile plates. The glass slides were made grease-free thoroughly. Each compound $(5 \mu \mathrm{L})$ in its subinhibitory concentration was added to each well along with control. Compounds $\mathbf{1}, \mathbf{2}, \mathbf{3 a}-\mathbf{g}$, and $\mathbf{4 a}-\mathbf{g}$ were added and incubated at $37{ }^{\circ} \mathrm{C}$ for $24 \mathrm{~h}$. The cells were treated and fixed using $2 \%$ paraformaldehyde. The glass slides were washed with $1 \times$ PBS buffer and imaged using confocal microscopy.

Methodology Used for Docking Studies. Three dimensional (3D) models of rice $\alpha / \beta$ glucosidase, rice $\alpha / \beta$ galactosidase, and Jack bean $\alpha$-mannosidase were built by comparative modeling using MODELER 9 v4. ${ }^{31}$ Crystallographic structures of homologous protein were considered as a template to predict the structures of enzymes, which were further assessed by the Ramachandran plot analysis. Structures of enzymes and synthesized molecules were energy-minimized using GROMOS43B1 energy field. Receptor and ligand molecules were prepared for docking simulation by adding hydrogens and assigning Kollman charges. Likewise, the ligands were established by assigning the Gasteiger charges and nonpolar hydrogens. Structures of receptor and ligand are converted from pdb to pdbqt format using AutoDock 4.2. ${ }^{32}$ Grid was set around the active site of enzymes with a dimension of $20 \times 20 \times 20 \AA^{3}$ using Autogrid module of Autodock program. Binding score was calculated by the Lamarckian genetic algorithm (LGA), which uses a set of 30 structurally known protein-ligand complexes with experimentally determined binding constants to calibrate empirical freeenergy functions. Parameters were set to the LGA calculation of 10000 runs, whereas energy evaluations were set to 1500000 and 27000 generations (repetition of process). The obtained docked poses and intermolecular interactions were gathered and analyzed using PyMol visualize (PyMol Molecular Graphics System, version $1.2 \mathrm{r} 3$ pre, Schrodinger LLC).

\section{ASSOCIATED CONTENT}

\section{Supporting Information}

The Supporting Information is available free of charge on the ACS Publications website at DOI: 10.1021/acsomega.7b01299.

${ }^{1} \mathrm{H}$ and ${ }^{13} \mathrm{C}$ spectra of new compounds, DFT-optimized coordinates and hydrogen-bonding parameters, binding energy of $\mathbf{1}, \mathbf{2}, \mathbf{3 a}-\mathbf{g}$, and $4 \mathbf{a}-\mathbf{g}$ with glycosidases, Lineweaver-Burk plots (PDF)

CIF files for 2 and $3 a$ (CIF) (CIF)

\section{AUTHOR INFORMATION}

\section{Corresponding Author}

*E-mail: ddd@chem.unipune.ac.in, dilipdhavale56@gmail.com. ORCID

Dilip D. Dhavale: 0000-0001-8221-6347

Notes

The authors declare no competing financial interest.

\section{ACKNOWLEDGMENTS}

The authors acknowledge SERB (File No. SERB/F/4158/ 2015-16) for financial support and Central Instrumental Facility (Savitribai Phule Pune University) for analytical support. S.R.C. and K.S.G. acknowledge CSIR New Delhi for providing fellowship as SRF. N.K. acknowledges UGC for providing DSK-PDF (BL/2014-15/0203).

\section{ADDITIONAL NOTES}

${ }^{a} \mathrm{~A}$ number of examples wherein piperidine, pyrrolidine, and azetidine spirocycled with various groups are known to be biologically important molecules.

${ }^{b}$ The best example of such multifunctional drug is artemisninquinine conjugate hybrid drug, which is more effective against drug-sensitive and drug-resistant malaria than the individual drugs.

${ }^{c}$ Only $3 \mathrm{c}$ and $4 \mathrm{c}$ were optimized, as all $\mathrm{N}$-alkyl derivatives $\mathbf{3 b}-\mathrm{g}$ and $\mathbf{4 b}-\mathbf{g}$ are showing nearly equivalent $J$ values as in $3 \mathbf{c}$ and $4 c$, respectively.

\section{REFERENCES}

(1) Iminosugars: From Synthesis to Therapeutic Applications; Compain, P., Martin, O. R, Eds.; John Wiley \& Sons: New York, 2007; p 7.

(2) (a) Wallace, D. C. Mitochondrial diseases in man and mouse. Science 1999, 283, 1482-1488. (b) Hedl, M.; Jie Yan, J.; Abraham, C. IRF5 and IRF5 disease-risk variants increase glycolysis and human M1 macrophage polarization by regulating proximal signaling and Akt2 activation. Cell Rep. 2016, 16, 2442-2455. (c) Cramer, T.; Yamanishi, Y.; Clausen, B.E.; Forster, I.; Pawlinski, R.; Mackman, N.; Haase, V. H.; Jaenisch, R.; Corr, M.; Nizet, V.; Firestein, G. S.; Gerber, H. P.; Ferrara, N.; Johnson, R. S. HIF-alpha is essential for myeloid cellmediated inflammation. Cell 2003, 112, 645-657. (d) FothergillGilmore, L. A. The evolution of the glycolytic pathway. Trends Biochem. Sci. 1986, 11, 47-51. (e) Murphy, J. P.; Pinto, D. M. Targeted proteomic analysis of glycolysis in cancer cell. J. Proteome Res. 2011, 10, 604-613. (f) Guo, X.; Li, H.; Xu, H.; Woo, S.; Dong, H.; Lub, F.; Lange, A. J.; Wu, C. Glycolysis in the control of blood glucose homeostasis. Acta Pharm. Sin. B 2012, 2, 358-367. (g) Arias, C.; Montiel, T.; Quiroz-Baez, R.; Massieu, L. $\beta$-Amyloid neurotoxicity Is exacerbated during glycolysis inhibition and mitochondrial impairment in the rat hippocampus in vivo and in isolated nerve terminals: implications for alzheimer's disease. Exp. Neurol. 2002, 176, 163-174. (h) Marsin, A.-S.; Bertrand, L.; Rider, M. H.; Deprez, J.; Beauloye, C.; Vincent, M. F.; Van den Berghe, G.; Carling, D.; Hue, L. Phosphorylation and activation of heart PFK-2 by AMPK has a role 
in the stimulation of glycolysis during ischaemia. Curr. Biol. 2000, 10, 1247-1255. (i) Powers, W. J.; Videen, T. O.; Markham, J.; McGeeMinnich, L.; Antenor-Dorsey, J. V.; Hershey, T.; Perlmutter, J. S. Selective defect of in vivo glycolysis in early Huntington's disease striatum. Proc. Natl. Acad. Sci. U.S.A. 2007, 104, 2945-2949. (j) Wu, S.-B.; Wei, Y.-H. AMPK-mediated increase of glycolysis as an adaptive response to oxidative stress in human cells: Implication of the cell survival in mitochondrial diseases. Biochim. Biophys. Acta, Mol. Basis Dis. 2012, 1822, 233-247.

(3) (a) Nair, S. S.; Kavrekar, V.; Mishra, A. In vitro studies on alpha amylase and alpha glucosidase inhibitory activities of selected plant extracts. Eur. J. Exp. Biol. 2013, 3, 128-132. (b) Thilagam, E.; Parimaladevi, B.; Kumarappan, C.; Mandal, S. C. $\alpha$-Glucosidase and $\alpha$ amylase inhibitory activity of Senna surattensis. J. Acupunct. Meridian Stud. 2013, 6, 24-30.

(4) (a) Geerlings, S. E.; Hoepelman, A. I. M. Immune dysfunction in patients with diabetes mellitus (DM). FEMS Immunol. Med. Microbiol. 1999, 26, 259-265. (b) Joshi, N.; Caputo, G. M.; Weitekamp, M. R.; Karchmer, A. W. Infections in patients with diabetes mellitus. N. Engl. J. Med. 1999, 1906-1912.

(5) Hsu, C.-R.; Chen, Y.-T.; Sheu, W. H.-H. Glycemic variability and diabetes retinopathy: A missing link. J. Diabetes Complications 2015, $29,302-306$

(6) (a) Mauer, S. M.; Steffes, M. W.; Ellis, E. N.; Sutherland, D. E. R.; Brown, D. M.; Goetz, F. C. Structural-functional relationship in diabetic nephropathy. J. Clin. Invest. 1984, 74, 1143-1155. (b) Gross, J. L.; Azevedo, M. J. D.; Silveiro, S. P.; et al. Diabetic nephropathy: diagnosis, prevention, and treatment. Diabetes Care 2005, 28, 164176. (c) Molitch, M. E.; DeFronzo, R. A.; Franz, M. J.; Keane, W. F.; Mogensen, C. E.; Parving, H.-H.; Steffes, M. W. Nephropathy in diabetes. Diabetes Care 2004, 27, S79-S83.

(7) (a) Said, G. Diabetic neuropathy-a review. Nat. Clin. Pract. Neurol. 2007, 3, 331-340. (b) Duby, J. J.; Campbell, R. K.; Setter, S. M.; White, J. R.; Rasmussen, K. A. Diabetic neuropathy: an intensive review. Am. J. Health Syst. Pharm. 2004, 61, 160-173.

(8) (a) Winston, J. A.; Miller, J. L. Treatment of onychomycosis in diabetic patients. Clin. Diabetes 2006, 24, 160-166. (b) Shah, B. R.; Hux, J. E. Quantifying the risk of infectious diseases for people with diabetes. Diabetes Care 2003, 26, 510-513. (c) Calvet, H. M.; Yoshikawa, T. T. Infections in diabetes. Infect. Dis. Clin. North Am. 2001, 15, 407-421. (d) Pozzilli, P.; Leslie, R. D. G. Infections in diabetes: mechanism and prospects for prevention. Diabetic Med. 1994, 11, 935-941. (e) Muller, L. M. A. J.; Gorter, K. J.; Hak, E.; Goudzwaard, W. L.; Schellevis, F. G.; Hoepelman, A. I. M.; Rutten, G. E. H. M. Increased risk of common infections in patients with type 1 and type 2 diabetes mellitus. Clin. Infect. Dis. 2005, 41, 281-288.

(9) (a) Ekezuea, B. F.; Laditka, S. B.; Laditka, J. N.; Studnicki, J.; Blanchette, C. M. Diabetes complications and adverse health outcomes after coronary revascularization. Diabetes Res. Clin. Pract. 2014, 103, 530-537. (b) Smith-Palmer, J.; Brandle, M.; Trevisan, R.; Orsini Federici, M.; Liabat, S.; Valentine, W. Assessment of the association between glucose variability and diabetes-related complications in type 1 and type 2 diabetes. Diabetes Res. Clin. Pract. 2014, 105, 273-284. (c) Sohda, T.; Mizuno, K.; Imamiya, E.; Tawada, H.; Meguro, K.; Kawamatsu, Y.; Yamamota, Y. Studies on antidiabetic agents. III. 5arylthiazolidine-2, 4-diones as potent aldose reductase inhibitors. Chem. Pharm. Bull. 1982, 30, 3601-3616. (d) Conwell, L. J.; Boult, C. The effects of complications and comorbidities on the quality of preventive diabetes care: a literature review. Popul. Health Manage. 2008, 11, 217-228. (e) Dvornik, D. Chronic complications of diabetes. Ann. Rep. Med. Chem. 1978, 13, 159-166.

(10) (a) Pozzilli, P.; Leslie, R. D. G. Infections in diabetes: mechanism and prospects for prevention. Diabetic Med. 1994, 11, 935-941. (b) Sravanthi, V.; Mayure, V. K.; Donthineni, K.; Meher, C. P.; Finny, G. J. A review on candidiasis: types and medications. PharmaTutor Mag. 2014, 2, 36-45. (c) Kali, A.; Srirangaraj, S.; Charles, M. V. P. Look for Diabetes mellitus in chronic fungal urinary tract infection. Res. J. Pharm., Biol. Chem. Sci. 2014, 5, 1285-1288.
(11) (a) Joubert, P. H.; Foukaridis, G. N.; Bopape, M. L. Miglitol may have a blood glucose lowering effect unrelated to inhibition of alpha-glucosidase. Eur. J. Clin. Pharmacol. 1987, 31, 723-724. (b) Joubert, P. H.; Venter, H. L.; Foukaridis, G. N. The effect of miglitol and acarbose after an oral glucose load: A novel hypoglycaemic mechanism? Br. J. Clin. Pharmacol. 1990, 30, 391396. (c) Mitrakou, A.; Tountas, N.; Raptis, A. E.; Bauer, R. J.; Schulz, H.; Raptis, S. A. Long-term effectiveness of a new $\alpha$-glucosidase inhibitor (BAY m1099- miglitol) in insulin-treated type 2 diabetes mellitus. Diabetic Med. 1998, 15, 657. (d) Van de Laar, F. A.; Lucassen, P. L. B. J.; Akkermans, R. P.; Van de Lisdonk, E. H.; Rutten, G. E. H. M.; Van Weel, C. Alpha-glucosidase inhibitors for type 2 diabetes mellitus. Cochrane Database Syst. Rev. 2005, 2, No. CD003639. (e) DeFronzo, R. A. Pharmacologic therapy for type 2 diabetes mellitus. Ann. Intern. Med. 1999, 131, 281-303. (f) Voss, A. A.; DiezSampedro, A.; Hirayama, B. A.; Loo, D. D. F.; Wright, E. M. Imino sugars are potent agonists of the human glucose sensor SGLT3. Mol. Pharmacol. 2007, 71, 628-634.

(12) (a) Sagatova, A. A.; Keniya, M. V.; Wilson, R. K.; Monk, B. C.; Tyndall, J. D. A. Structural insights into binding of the antifungal drug fluconazole to Saccharomyces cerevisiae lanosterol $14 \alpha$-demethylase. Antimicrob. Agents Chemother. 2015, 59, 4982-4989. (b) Kowalsky, S. F.; Dixon, D. M. Fluconazole: a new antifungal agent. Clin. Pharm. 1991, 10, 179-194.

(13) (a) Peters, J.-U. Polypharmacology- foe or friend? J. Med. Chem. 2013, 56, 8955-8971. (b) Yoshioka, T.; Fujita, T.; Kanai, T.; Aizawa, Y.; Kurumada, T.; Hasegawa, K.; Horikoshi, H. Studies on hindered phenols and analogues. 1. hypolipidemic and hypoglycemic agents with ability to inhibit lipid peroxidation. J. Med. Chem. 1989, 32, 421428. (c) Bansal, Y.; Silakari, O. Multifunctional compounds: smart molecules for multifunctional diseases. Eur. J. Med. Chem. 2014, 76, 31-42. (d) Stahl, S. M. Depression and Bipolar Disorder: Stahl's Essential Psychopharmacology, 3rd ed.; Cambridge University Press: New York, 2008. (e) Li, K.; Schurig-Briccio, L. A.; Feng, X.; Upadhyay, A.; Pujari, V.; Lechartier, B.; Fontes, F. L.; Yang, H.; Rao, G.; Zhu, W.; Gulati, A.; No, J. H.; Cintra, G.; Bogue, S.; Liu, Y.-L.; Molohon, K.; Orlean, P.; Mitchell, D. A.; Freitas-Junior, L.; Ren, F.; Sun, H.; Jiang, T.; Li, Y.; Guo, R.-T.; Cole, S. T.; Gennis, R. B.; Crick, D. C.; Oldfield, E. Multitarget drug discovery for tuberculosis and other infectious diseases. J. Med. Chem. 2014, 57, 3126-3139.

(14) (a) Bisi, A.; Rampa, A.; Budriesi, R.; Gobbi, S.; Belluti, F.; Ioan, P.; Valoti, E.; Chiarini, A.; Valenti, P. Cardiovuscular hybrid drugs: new benzazepinone derivatives as bradycardic agents endoved with selective $\beta 1$-non-competitive antagonism. Bioorg. Med. Chem. 2003, 11, 1353-1361. (b) Lahiri, R.; Ansari, A. A.; Vankar, Y. D. Recent development in design and synthesis of bicyclic azasugars, carbasugars and related molecules as glycosidase inhibitors. Chem. Soc. Rev. 2013, 42, 5102-5118. (c) Aminake, M. N.; Mahajan, A.; Kumar, V.; Hans, R.; Wiesner, L.; Taylor, D.; de Kock, C.; Grobler, A.; Smith, P. J.; Kirschner, M.; Rethwilm, A.; Pradel, G.; Chibale, K. Synthesis and evaluation of hybrid drugs for a potential HIV/AIDS-malaria combination therapy. Bioorg. Med. Chem. 2012, 20, 5277-5289.

(15) (a) Zhou, Y.; Zhao, Y.; Boylea, K. M. O.; Murphy, P. V. Hybrid angiogenesis inhibitors: synthesis and biological evaluation of bifunctional compounds based on 1-deoxynojirimycin and aryl-1,2,3triazoles. Bioorg. Med. Chem. 2008, 18, 954-958. (b) Panday, N.; Canac, Y.; Vasella, A. Very strong inhibition of glucosidases by $C(2)$ substituted tetrahydroimidazopyridines. Helv. Chim. Acta. 2000, 83, 58-79. (c) Dolhem, F.; Tahli, F. A.; Lievre, C.; Demailly, G. Efficient synthesis of 1,2,3-triazole fused bicyclic compounds from aldoses. Eur. J. Org. Chem. 2005, 5019-5023. (d) García-Moreno, M. I.; Diaz-Perez, P.; Mellet, C. O.; Fernandez, J. M. G. Castanospermine-trehazolin hybrids: a new family of glycomimetics with tunable glycosidase inhibitory properties. Chem. Commun. 2002, 8, 848-849. (e) Marotte, K.; Ayad, T.; Genisson, Y.; Besra, G. S.; Baltas, M.; Prandi, J. Synthesis and biological evaluation of imino sugar-oligoarabinofuranoside hybrids, a new class of mycobacterial arabinofuranosyltransferase inhibitors. Eur. J. Org. Chem. 2003, 14, 2557-2565. (f) Sturm, M. B.; Roday, S.; Schramm, V. L. Circular DNA and DNA/RNA hybrid 
molecules as scaffolds for ricin inhibitor design. J. Am. Chem. Soc. 2007, 129, 5544-5550.

(16) For antitubercular activity ref 1 , page 366 and for $\alpha$ rhamnosidase inhibitory: Davis, B. G.; Brandstetter, T. W.; Hackett, L.; Winchester, B. G.; Nash, R. J.; Watson, A. A.; Griffiiths, R. C.; Smith, C.; Fleet, G. W. J. Tetrazoles of manno- and rhamno-pyranoses: contrasting inhibition of mannosidases by [4.3.0] but of rhamnosidase by [3.3.0] bicyclic tetrazoles. Tetrahedron 1999, 55, 4489-4500.

(17) (a) Blériot, Y.; Tran, A. T.; Prencipe, G.; Jagadeesh, Y.; Auberger, N.; Zhu, S.; Gauthier, C.; Zhang, Y.; Desire, J.; Adachi, I.; Kato, A.; Sollogoub, M. Synthesis of 1,2-trans-2-acetamido-2deoxyhomoiminosugars. Org. Lett. 2014, 16, 5516-5519. (b) Aoyama, T.; Naganawa, H.; Suda, H.; Uotani, K.; Aoyagi, T.; Takeuchi, T. J. Synthesis of 1,2-trans-2-acetamido-2-deoxyhomoiminosugars. J. Antibiot. 1992, 45, 1557-1558. (c) Terinek, M.; Vasella, A. Synthesis of Nacetylglucosamine-derived negstatin analogues and their evaluation as glycosidase inhibitors. Helv. Chim. Acta 2005, 88, 10-22.

(18) (a) Carreira, E. M.; Fessard, T. C. Four membered ring containing spirocycles: synthetic strategic and opportunities. Chem. Rev. 2014, 114, 8257-8322. (b) Singh, G. S.; Desta, Z. Y. Isatins as privileged molecules in design and synthesis of spiro-fused cyclic frameworks. Chem. Rev. 2012, 112, 6104-6155. (c) Kuznetsov, N. Y.; Bubnov, Y. N. Ruthenium-catalyzed intramolecular metathesis of dienes and its application in the synthesis of bridged and spiro azabicycles. Russ. Chem. Rev. 2015, 84, 758-785.

(19) Laroche, C.; Behr, J.-B.; Szymoniak, J.; Bertus, P.; Schutz, C.; Vogel, P.; Plantier-Royon, R. Spirocyclopropyl pyrrolidines as a new series of $\alpha$-L-fucosidase inhibitors. Bioorg. Med. Chem. 2006, 14, 40474054.

(20) Pal, P. J.; Gupta, P.; Reddy, Y. S.; Vankar, Y. D. Synthesis of fused oxa-aza spiro sugars from $\mathrm{D}$-glucose-derived $\delta$-lacton as glycosidase inhibitors. Eur. J. Org. Chem. 2010, 6957-6966.

(21) (a) Nocquet, P.-A; Hensienne, R.; Wencel-Delord, J.; Wimmer, E.; Hazelard, D.; Compain, P. Synthesis of a new class of iminosugars based on constrained azaspirocyclic scaffolds by way of catalytic $\mathrm{C}-\mathrm{H}$ amination. Org. Biomol. Chem. 2015, 13, 9176. (b) Nocquet, P.-A; Hensienne, R.; Wencel-Delord, J.; Wimmer, E.; Laigre, E.; Sidelarbi, K.; Becq, F.; Norez, C.; Compain, P. Pushing the limits of catalytic C$\mathrm{H}$ amination in polyoxygenated cyclobutanes. Org. Biomol. Chem. 2016, 14, 2780-2796.

(22) Parihar, V.; Pawar, N. J.; Ghosh, S.; Chopade, B.; Kumbhar, N.; Dhavale, D. D. Diazaspiro-iminosugars polyhydroxylated spirobislactams: synthesis, glycosidase inhibition and molecular docking studies. RSC Adv. 2015, 5, 52907-52915.

(23) (a) Walsh, J. J.; Coughlan, D.; Heneghan, N.; Gaynora, C.; Bell, A. A novel-artemisinin-quinine hybrid with potent antimalarial activity. Bioorg. Med. Chem. Lett. 2007, 17, 3599-3602. (b) Saadeh, H. A.; Mosleh, I. M.; Mubarak, M. S. Synthesis of novel hybrid molecules from precursors with known antiparasitic activity. Molecules 2009, 14, $1483-1494$.

(24) (a) Chavan, S. R.; Gavale, K. S.; Kamble, K. M.; Pingale, S. S.; Dhavale, D. D. gem-Disubstituent effect in rate acceleration of intramolecular alkyne-azide cycloaddition reaction. Tetrahedron 2017, 73, 365-372. Seminal references- (b) Heightman, T. D.; Locatelli, M.; Vasella, A. Synthesis of fused triazoles as probes for the active site of retaining $\beta$-glycosidases: from which direction is the glycoside protonated? Helv. Chim. Acta 1996, 79, 2190-2200. (c) Panday, N.; Meyyappan, M.; Vasella, A. A comparison of glucose- and glucosamine-related inhibitors: probing the interaction of the 2-hydroxy group with retaining $\beta$-glucosidases. Helv. Chim. Acta 2000, 83, 513538. (d) Tezuka, K.; Compain, P.; Martin, O. R. Synthesis of polyhydroxylated tetrahydro- $4 H-1,2,3$-triazolo[1,5-a]azepine, a higher homolog of "nojiritriazole", and of a related C-diasaccharide. Synlett 2000, 12, 1837-1839.

(25) (a) Tan, A.; van den Broek, L.; van Boeckel, S.; Ploegh, H.; Bolscher, J. Chemical modification of the glucosidase inhibitor 1deoxynojirimycin. J. Biol. Chem. 1991, 266, 14504-14510. (b) van den Broek, L. A. G. M.; Vermaas, D. J.; Heskamp, B. M.; van Boeckel, C. A. A.; Tan, M. C. A. A.; Bolscher, J. G. M.; Ploegh, H. L.; van Kemenade,
F. J.; de Goede, R. E. Y.; Miedema, F. Chemical modification of azasugars, inhibitors of $\mathrm{N}$-glycoprotein-processing glycosidases and of HIV-I infection. Recl. Trav. Chim. Pays-Bas 1993, 112, 82-94. (c) Butters, T. D.; van den Broek, L.; Fleet, G. W. J.; Krulle, T. M.; Wormald, M. R.; Dwek, R. A.; Platt, F. M. Molecular requirements of imino sugars for the selective control of $\mathrm{N}$-linked glycosylation and glycosphingolipid biosynthesis. Tetrahedron: Asymmetry 2000, 11, $113-124$.

(26) Patil, N. T.; John, S.; Sabharwal, S. G.; Dhavale, D. D. 1-Azasugars from D-glucose. preparation of 1-deoxy-5-dehydroxymethylnojirimycin, its analogues and evaluation of glycosidase inhibitory activity. Bioorg. Med. Chem. 2002, 10, 2155-2160.

(27) Oikonomakos, N. G.; Tiraidis, C.; Leonidas, D. D.; Zographos, S. E.; Kristiansen, M.; Jessen, C. U.; Norskov-Lauritsen, L.; Agius, L. Iminosugars as potential inhibitors of glycogenolysis: structural insights into the molecular basis of glycogen phosphorylase inhibition. J. Med. Chem. 2006, 49, 5687-5701.

(28) Gottlieb, H. E.; Kotlyar, V.; Nudelman, A. NMR chemical shifts of common laboratory solvents as trace impurities. J. Org. Chem. 1997, $62,7512-7515$.

(29) (a) Ferreira, S. B.; Sodero, A. C. R.; Cardoso, M. F. C.; Lima, E. S.; Kaiser, C. R.; Silva, F. P., Jr.; Ferreira, V. F. Synthesis, biological activity, and molecular modeling studies of $1 \mathrm{H}-1,2,3$-triazole derivatives of carbohydrates as $\alpha$-glucosidases inhibitors. J. Med. Chem. 2010, 53, 2364-2375. (b) Gonzaga, D.; Senger, M. R.; da Silva, F. d. C.; Ferreira, V. F.; Silva, F. P., Jr. 1-Phenyl-1H- and 2-phenyl-2H1,2,3-triazol derivatives: design, synthesis and inhibitory effect on alpha-glycosidases. Eur. J. Med. Chem. 2014, 74, 461-476.

(30) (a) Aher, N. G.; Pore, V. S.; Mishra, N. N.; Kumar, A.; Shukla, P. K.; Sharma, A.; Bhat, M. K. Synthesis and antifungal activity of 1,2,3-triazole containing fluconazole analogue. Bioorg. Med. Chem. Lett. 2009, 19, 759-763. (b) Dai, Z.-C.; Chen, Y.-F.; Zhang, M.; Li, S.-K.; Yang, T.-T.; Shen, L.; Wang, J.-X.; Qian, S.-S.; Zhue, H.-L.; Ye, Y.-H Synthesis and antifungal activity of 1,2,3-triazole phenylhydrazone derivatives. Org. Biomol. Chem. 2015, 13, 477-486. (c) Holla, B. S.; Mahalinga, M.; Karthikeyan, M. S.; Poojary, B.; Akberali, P. M.; Nalilu, S. K. Synthesis, characterization and antimicrobial activity of some substituted 1,2,3-triazoles. Eur. J. Med. Chem. 2005, 40, 1173-1178. (d) Haider, S.; Alam, M. S.; Hamid, H. 1, 2, 3-Triazoles: scaffold with medicinal significance. Inflammation Cell Signaling 2014, 1, No. e95. (e) Qin, Y.; Liu, S.; Xing, R.; Li, K.; Yu, H.; Li, P. Synthesis and antifungal evaluation of (1,2,3-triazol-4-yl)methyl nicotinate chitosan. Int. J. Biol. Macromol. 2013, 61, 58-62. (f) Wei, J.-J.; Jin, L.; Wan, K.; Zhou, C.-H. Synthesis of novel D-glucose-derived benzyl and alkyl 1,2,3-triazoles as potential antifungal and antibacterial agents. Bull. Korean Chem. Soc. 2011, 32, 229-238. (g) Ren, Y.; Zhang, L.; Zhou, C.-H.; Geng, R.-X. Recent development of benzotriazole-based medicinal drugs. Med. Chem. 2014, 4, 640-662. (h) Lima-Neto, R. G.; Cavalcante, N. N. M.; Srivastava, R. M.; Mendonça, F. J. B., Jr.; Wanderley, A. G.; Neves, R. P.; dos Anjos, J. V. Synthesis of 1,2,3triazole derivatives and in vitro antifungal evaluation on candida strains. Molecules 2012, 17, 5882-5892.

(31) Eswar, N.; Marti-Renom, M. A.; Webb, B.; Madhusudhan, M. S.; Eramian, D.; Shen, M.; Pieper, U.; Sali, A. Comparative protein structure modeling UNIT 5.6 uusing modeller. Current Protoc. Bioinf. 2006, 15, 1-5.

(32) Morris, G. M.; Huey, R.; Lindstrom, W.; Sanner, M. F.; Belew, R. K.; Goodsell, D. S.; Olson, A. J. AutoDock4 and AutoDockTools4: automated docking with selective receptor flexibility. J. Comput. Chem. 2009, 30, 2785-2791. 